\title{
Novel immunotherapies in lymphoid malignancies
}

\section{Connie Lee Batlevi ${ }^{1}$, Eri Matsuki ${ }^{1}$, Renier J. Brentjens ${ }^{2}$ and Anas Younes ${ }^{1}$}

Abstract | The success of the anti-CD20 monoclonal antibody rituximab in the treatment of lymphoid malignancies provided proof-of-principle for exploiting the immune system therapeutically. Since the FDA approval of rituximab in 1997, several novel strategies that harness the ability of T cells to target cancer cells have emerged. Reflecting on the promising clinical efficacy of these novel immunotherapy approaches, the FDA has recently granted 'breakthrough' designation to three novel treatments with distinct mechanisms. First, chimeric antigen receptor (CAR)-T-cell therapy is promising for the treatment of adult and paediatric relapsed and/or refractory acute lymphoblastic leukaemia (ALL). Second, blinatumomab, a bispecific T-cell engager $\left(\mathrm{BiTE}^{\circledR}\right)$ antibody, is now approved for the treatment of adults with Philadelphia-chromosomenegative relapsed and/or refractory B-precursor ALL. Finally, the monoclonal antibody nivolumab, which targets the PD-1 immune-checkpoint receptor with high affinity, is used for the treatment of Hodgkin lymphoma following treatment failure with autologous-stem-cell transplantation and brentuximab vedotin. Herein, we review the background and development of these three distinct immunotherapy platforms, address the scientific advances in understanding the mechanism of action of each therapy, and assess the current clinical knowledge of their efficacy and safety. We also discuss future strategies to improve these immunotherapies through enhanced engineering, biomarker selection, and mechanism-based combination regimens.

The concept of immunotherapy for treating cancer emerged almost a century ago; the graft-versus-tumour effect following allogeneic haematopoietic-stem-cell transplantation (HSCT) was one of the first examples of immunotherapy ${ }^{1}$. Furthermore, the success of rituximab in treating lymphoid malignancies provided proof-ofprinciple for exploiting the immune system in a targetspecific manner ${ }^{2-4}$. With improved technology and a better understanding of immune-regulatory mechanisms, cancer immunotherapy is rapidly evolving to exploit the therapeutic value of activating autologous $\mathrm{T}$ cells.

The types of immunotherapy available for haematological malignancies range from cell-based to antibodybased therapies. Early attempts with cell-based therapies focused on the adoptive transfer of cytotoxic $\mathrm{T}$ lymphocytes (CTLs) that targeted tumour-associated antigens (TAAs). The success of this approach using WT-1-specific and Epstein-Barr virus (EBV)-specific CTLs has been reported for various lymphoproliferative disorders, including acute lymphoblastic leukaemia (ALL), Hodgkin lymphoma (HL), and post-transplantation lymphoproliferative disorder (PTLD) ${ }^{5-9}$. The excitement of cell-based therapy was followed by the use of engineered chimeric antigen receptor (CAR) $\mathrm{T}$ cells, a type of cell-based therapy directed at TAAs expressed on the tumour-cell surface, typically CD19 in B-cell malignancies (BOX 1). Antibody-based therapies include a variety of immune-checkpoint-inhibitor-based therapies that either block anergic signals from tumour cells, or enhance T-cell activation directly. Bispecific T-cell engagers $\left(\mathrm{BiTE}^{\circledR}\right)$ direct $\mathrm{T}$ cells to target TAAs (FIG. 1).

The three distinct classes of drugs, CAR T cells, bispecific antibodies and immune-checkpoint inhibitors, have been granted 'breakthrough' designation by the US FDA; one such agent, the BiTE ${ }^{\circledR}$ blinatumomab, has already received approval by the FDA for the treatment of Philadelphia-chromosome (Ph)-negative relapsed and/or refractory B-precursor ALL (B-ALL). Each treatment approach is based on unique platforms that will probably encourage development of further therapeutic agents in the future. In this article, we review these platforms, and discuss the emerging clinical activity and unique toxicity.

\section{Engineered CAR T cells}

CAR T cells are autologous $\mathrm{T}$ lymphocytes that are genetically engineered to express the binding site of specific antibodies, thereby directing the autologous polyclonal $\mathrm{T}$ cells to bind a specific TAA. The construct 


\section{Key points \\ - Immunotherapies that activate T-cell responses against tumour cells have been successful in the treatment of lymphoid malignancies \\ - Second-generation chimeric antigen receptor (CAR) T cells targeting CD19-expressing B cells have shown promise in B-lymphoid malignancies \\ - Both CAR-T-cell therapy and blinatumomab produce adverse effects related to T-cell activation, in the form of cytokine-release syndrome and central-nervous-system- related symptoms \\ - Immune-checkpoint inhibitors demonstrated significant clinical activity against Hodgkin lymphoma \\ - Further understanding of each of these treatment modalities will establish the role of immunotherapy as a key component in the management of lymphoid malignancies}

is composed of a single-chain variable fragment $(\mathrm{scFv})$ of an antibody fused to the activating intracellularsignalling domain of the T-cell receptor (TCR), typically the $\zeta$ signalling domain (FIG. 2a) $)^{10-12}$. Polyclonal CAR $\mathrm{T}$ cells recognize their target antigen through the antibody domain resulting in T-cell activation independent of major histocompatibility complex (MHC) presentation $^{13}$. The scFvs are constructed by cloning the heavy and light chain variable regions of an antigen-specific monoclonal antibody, separated by a short peptide linker, into a single polypeptide ${ }^{14-16}$. DNA encoding this construct can be transduced ex vivo using transfection, gamma retroviral or lentiviral recombinant vectors, or a transposon system ${ }^{17-22}$. Various CAR-T-cell constructs exist with distinct scFvs and signalling domains (FIG. 2b). Knowledge of CD19-directed CAR T cells is more established than that of other forms, with published studies from the Memorial Sloan-Kettering Cancer Center (MSKCC; New York, NY, USA), the University of Pennsylvania (UPenn; Philadelphia, PA, USA), and the National Cancer Institute (NCI; Bethesda, MA, USA). CAR-T-cell constructs from the MSKCC, the NCI, and also the Baylor College of Medicine (Houston, TX, USA) share a common gammaretroviral vector and a CD28 signalling domain ${ }^{20,23,24}$. By comparison, constructs developed at the City of Hope Comprehensive Cancer Center (Duarte, CA, USA), UPenn, and Fred Hutchinson

\section{Box 1 | Glossary of terms}

- Chimeric antigen receptor T cells: engineered receptors with specificity of a monoclonal antibody grafted onto a T cell

- Bispecific monoclonal antibodies: fusion proteins composed of fragments of two different monoclonal antibodies and therefore binds two different antigens

- Immune-checkpoint receptors: cell-surface molecules expressed by $\mathrm{T}$ cells or normal tissue that helps maintain self-tolerance and control the intensity and duration of an immune response

- Overall response rate: reduction in tumour burden meeting criteria for complete or partial responses

- Complete response: disappearance of all target lesions

- Partial response: at least a $50 \%$ reduction in the sum of longest diameters for all target lesions
Cancer Research Center (Seattle, WA, USA) use a lentiviral transfection system ${ }^{25-27}$. The MD Anderson Cancer Center (Houston, TX) continues to develop the Sleeping Beauty transposon system, which combines the advantages of viruses and naked DNA. The advantages and limitations of each approach have not been fully elucidated at this point; however, potential differences include the expression level of CARs, persistence of cells, safety (including the potential for carcinogenesis), manufacturing efficacy, and costs. Lentiviral and retroviral delivery could potentially result in integration of the CAR construct proximally to growth-promoting genes, leading to malignant transformation. In the cumulative experience of using viral-based CAR T cells, insertional mutagenesis has not been reported. Transposon systems have a lower risk of insertional mutagenesis, but CAR transgene expression is much lower with this approach. The antigen-binding domain varies between the different CAR constructs, with most researchers using either the mouse hybridoma derived FMC63 or SJ25C1 CD19 $\mathrm{scFv}$ constructs ${ }^{28,29}$. Both constructs have been developed to target CD19-positive cells of haematological malignancies, and have shown efficacy in various in vitro and in vivo models. However, whether differences in CAR constructs or the inherent design of CAR T cells provides advantages over other immunotherapies remains unclear, as these approaches have not been compared in randomized controlled trials ${ }^{21,30,31}$.

CAR T cells can be further modified to increase their efficacy and durability by the incorporation of costimulatory domains (FIG. 2C). Clinical studies of firstgeneration CAR T cells that were generated to treat B-cell malignancies (by targeting CD20 or CD19 antigens) demonstrated the feasibility of this approach; however, these engineered cells lacked significant antitumour activity, probably because of inadequate CAR-T-cell persistence ${ }^{32,33}$. Second-generation and third-generation CAR designs incorporated one or two co-stimulatory signalling domains. Second-generation receptors are capable of delivering both a primary activation signal through the TCR $\zeta$-chain as well as a co-stimulatory signal through the CD28 or 4-1BB domains in the cytoplasmic tail $^{34,35}$. Clinical studies showed that second-generation CARs resulted in improved in vivo expansion and persistence of the transfected $\mathrm{T}$ cells ${ }^{24}$. Third-generation CARs contain two co-stimulatory domains, with the first consisting of a CD28 or 4-1BB domain and the second provided by other molecules, such as OX40, CD28, or $4-1 \mathrm{BB}^{36-39}$. Fourth-generation 'armoured CAR' T cells are engineered to additionally express cytokines or costimulatory ligands, which aim to enhance expansion and longevity of the CAR T cells ${ }^{40}$. Additional innovations in the technology include introduction of a suicide-gene system, which can be activated to control the expansion of CAR T cells and thereby minimize excessive toxicity ${ }^{41}$. The efficacy of CAR-T-cell therapy can be improved by modulating homing mechanisms through expression of chemokine receptors, such as CCR4 or CXCR2, on the modified $\mathrm{T}$ cells, or by including lymphodepleting chemotherapy ${ }^{42,43}$. Preconditioning lymphodepleting therapy decreases antigen load by reducing the number 


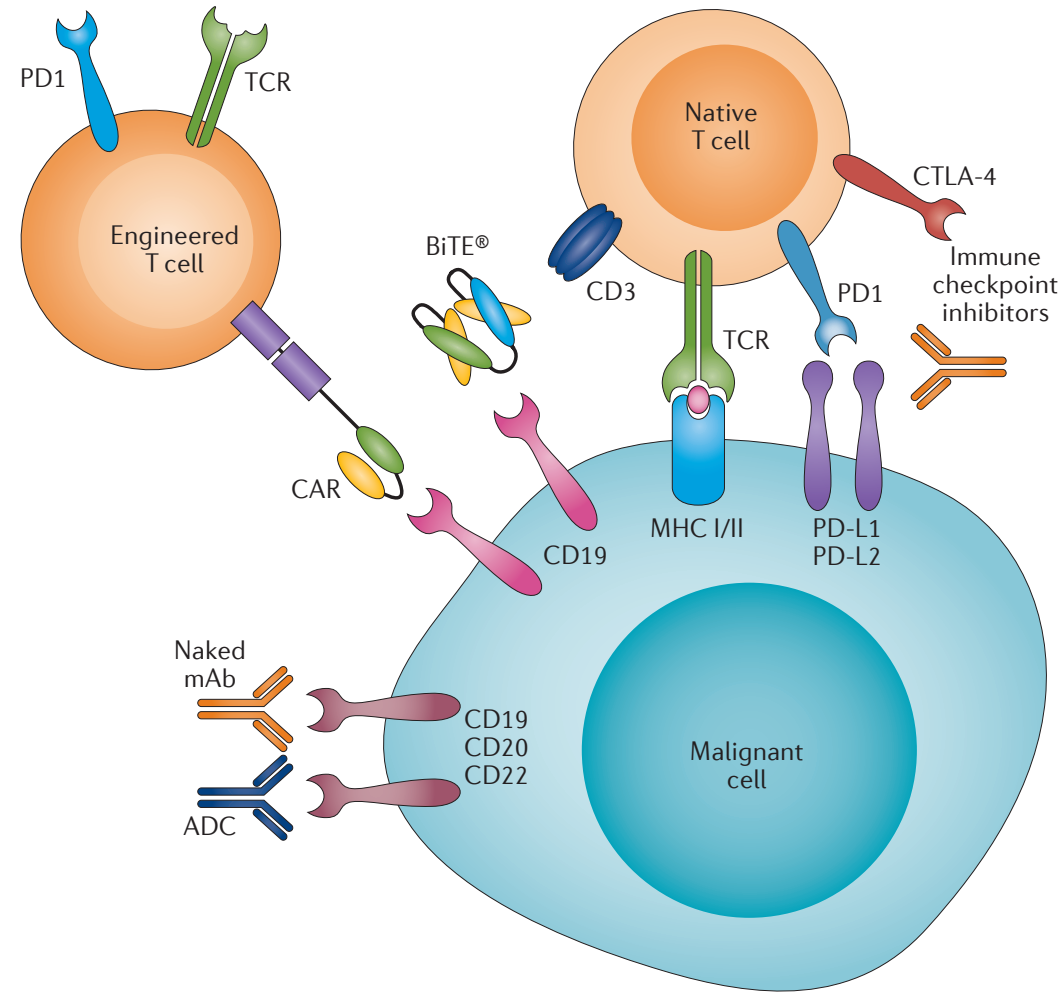

Figure 1 | Mechanisms of action of immunotherapy modalities. Native T cells can recognize tumour-specific antigens in an $\mathrm{MHC}$-dependent manner. The T cells also require co-stimulation for activation. Upon antigen recognition, without co-stimulatory signal, or with the stimulation of inhibitory molecules, such as through the PD-1-PD-L1 axis, the T cells can be induced to anergy or become exhausted. Immune-checkpoint inhibitors can block the inhibitory signal of T cells to avert T cells from anergy. BiTE ${ }^{\circledR}$ antibodies bring $T$ cells and malignant cells into close proximity through dual antigen binding, and can induce T-cell activation without co-stimulatory signals. T-cells can also be engineered to express CARs to recognize cell-surface molecules independent of MHC. Later-generation CARs have both TCR and co-stimulatory signalling components, thereby activating the $T$ cells without additional co-stimulatory signal. Abbreviations: ADC, antibody-drug conjugate; $\mathrm{BiTE}^{\circledR}$, bispecific T-cell engager antibody; CAR, chimeric antigen receptor; CTLA-4, cytotoxic T-lymphocyte-associated protein 4; mAb, monoclonal antibody; MHC, major histocompatibility complex; PD-1, programmed cell death protein 1; PD-L1, programmed cell death 1 ligand 1; TCR, T-cell receptor.

of tumour cells, and also depletes immunosuppressive cells in the tumour microenvironment, which promotes pro-survival cytokine signals that lead to expansion and persistence of CAR T cells. Clinical studies in lymphoid malignancies have focused on second-generation CAR $\mathrm{T}$ cells that target CD19-expressing B-cell malignancies; however, the use of different CAR constructs and transfection methods between clinical trials hampers the ability to compare results across different groups (FIG. 2b) ${ }^{22,44-46}$.

Generation of clinical-grade CAR T cells begins with apheresis of a patient's peripheral blood mononuclear cells (PBMCs) for ex vivo transduction and expansion. Apheresis occurs over 1-2 days and the product is frozen until the time of transduction. Isolated PBMCs are then thawed and the T cells are activated and selected by incubation with anti-CD3 and anti-CD28 paramagnetic beads. The activated $\mathrm{T}$ cells are then transduced with retroviral or lentiviral vectors carrying the
CAR construct ${ }^{19,26}$, or at some centres, electroporation is used to introduce a transposon or plasmid to the activated $\mathrm{T}$ cells ${ }^{22,33}$. Finally, the T cells are expanded 1,000-fold via co-stimulation with CD3 and CD28 $8^{17,47}$. CAR-T-cell doses that range from $1.5 \times 10^{6} / \mathrm{kg}$ to $3 \times 10^{7} / \mathrm{kg}$ are achieved over a culture period of $1-2$ weeks. This product contains a mixture of CD4-positive and CD8-positive T cells as well as regulatory and memory $\mathrm{T}$ cells, at varying ratios. CAR $\mathrm{T}$ cells are infused into the patient over 1-2 days as single or split doses - the latter is preferred for safety and monitoring of immediate toxicities. Inpatient admission is commonly required to monitor for CAR-T-cell-related toxicities including cytokine-release syndrome (CRS) and central nervous system (CNS) toxicities. The duration of admission is variable and can be as short as 5-10 days, with discharge dictated by the patient's clinical condition. In vivo, CAR T cells expand 1,000-10,000-fold with T-cell persistence of weeks to years, although prolonged T-cell persistence is found only in a minority of patients. In the following section, we review the published clinical trial data on the use of CAR T cells in patients with lymphoid malignancies.

\section{Clinical data with CAR T cells}

Acute lymphoblastic leukaemia. To date, CAR-T-cell therapies have been most efficacious in patients with B-cell ALL (TABLE 1). At the MSKCC, most patients treated with CAR $\mathrm{T}$ cells have been adults, whereas other groups treated both paediatric and adult patients. Despite differences in the CAR constructs used, conditioning regimens, infused T-cell doses and patient populations, three published studies reported similar complete response (CR) rates of 70-90\% ${ }^{44,48-52}$. Investigators at the MSKCC published the first report of CAR-T-cell therapy in patients with ALL using a second-generation CD19-targeted CAR T cell with both a TCR zeta-chain and CD28 signalling domain (19-28z CAR T-cell). One patient was treated with 19-28z-CAR T cells after second remission presented with prolonged B-cell aplasia while waiting for allogeneic HSCT ${ }^{44}$. The patient was successfully treated with allogeneic HSCT, but died unexpectedly of pulmonary embolism 2 months post HSCT while in complete remission from $\mathrm{ALL}^{49}$. A follow-up study with 19-28z-CAR T cells demonstrated a high response rate, whereby all five treated patients achieved remission and tested negative for minimal residual disease $(M R D)^{48}$. On the basis of data from 22 evaluable patients treated at MSKCC, the median overall survival after 19-28z-CAR-T-cell therapy was 9 months ${ }^{49,50}$. The number of treated patients is small, with limited follow up; however, the response rate and survival rates have generated a considerable excitement, considering that more than half of the patients had undergone multiple lines of treatment before CAR-T-cell therapy ${ }^{53-55}$. At UPenn, 30 patients with ALL who were treated with CAR T cells demonstrated 6-month event-free-survival (EFS) and overall-survival rates of $67 \%$ and $78 \%$, respectively ${ }^{51}$. Outcomes of 20 patients treated at the NCI revealed a leukaemia-free survival rate of $79 \%$ at 5 months $^{52}$. At all three centres, CAR T cells have been given successfully 


\section{REVIEWS}

a

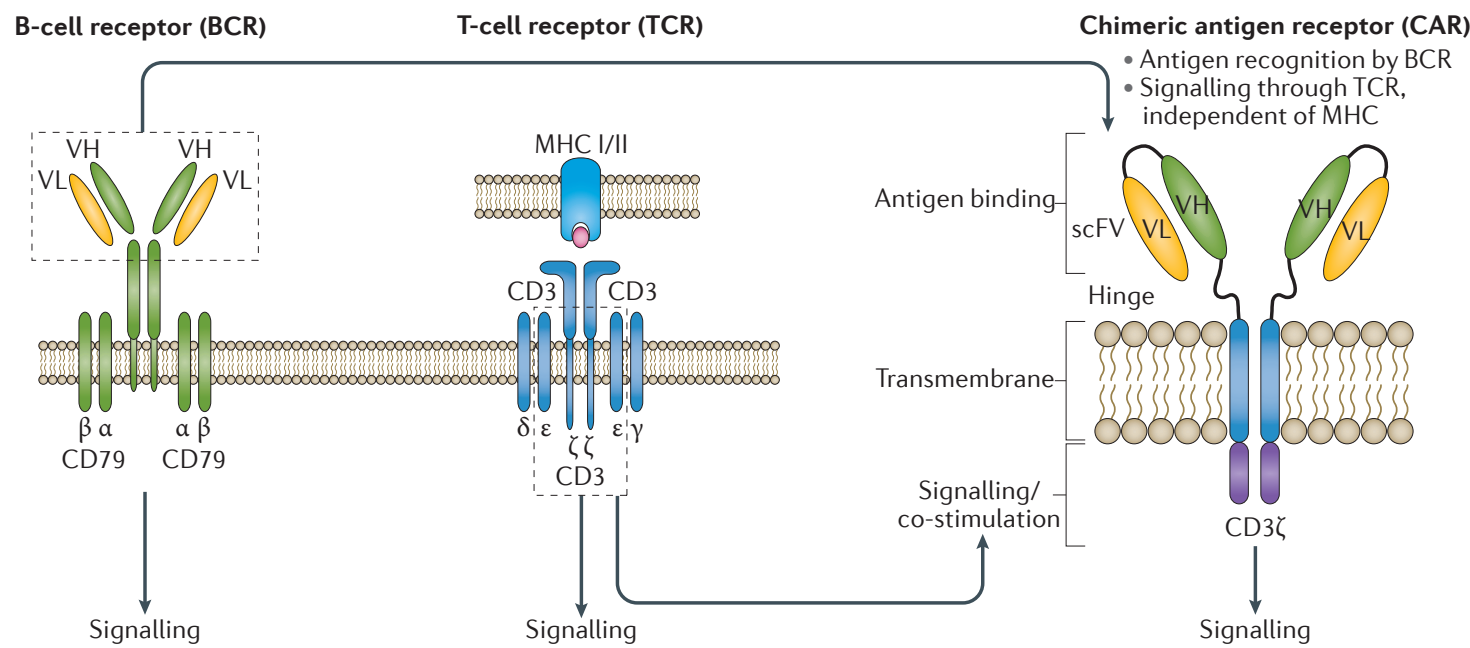

b

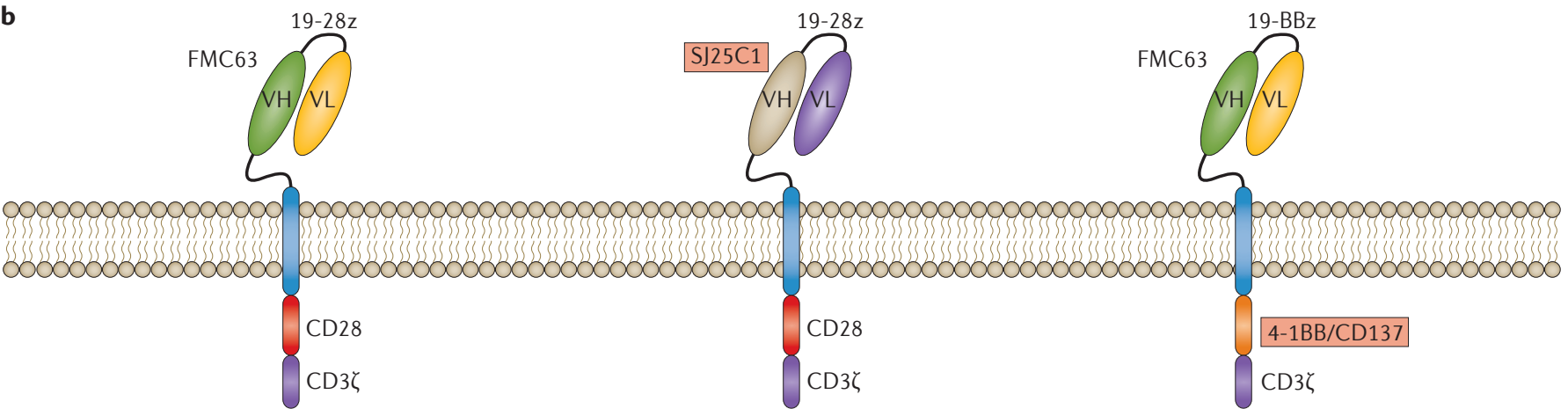

\begin{tabular}{|ccc|}
\hline Institute & Transfection & $\begin{array}{c}\text { Hinge/ } \\
\text { transmembrane }\end{array}$ \\
\hline $\mathrm{NCl}$ & Retrovirus & $\mathrm{CD} 28$ \\
\hline Baylor & Retrovirus & $\operatorname{lgG}-\mathrm{CD} 28$ \\
\hline City of hope & Lentivirus & $\operatorname{lgG} 4-\mathrm{Fc}$ \\
\hline MDACC & Sleeping beauty & $\operatorname{lgG} 4-\mathrm{Fc}$ \\
\hline Fred Hutchinson & Lentivirus & $\operatorname{lgG1}$-CD4 \\
\hline
\end{tabular}

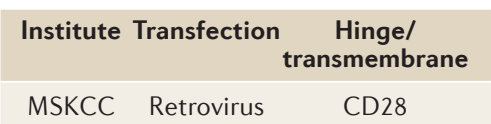

MSKCC Retrovirus

\begin{tabular}{|llc|}
\hline Institute & Transfection & $\begin{array}{c}\text { Hinge/ } \\
\text { transmembrane }\end{array}$ \\
\hline U Penn (CTL019) & Lentivirus & CD8 \\
\hline Fred Hutchinson & Lentivirus & IgG1-CD4 \\
\hline
\end{tabular}

c

$1^{\text {st }}$ generation

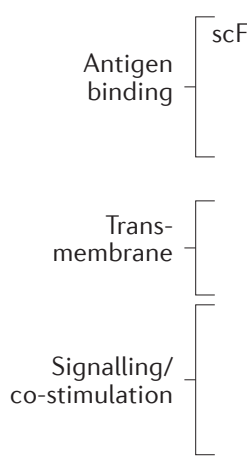

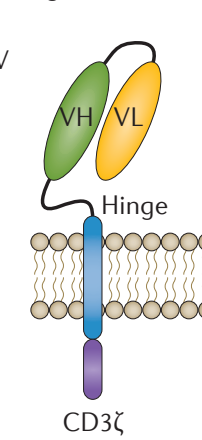

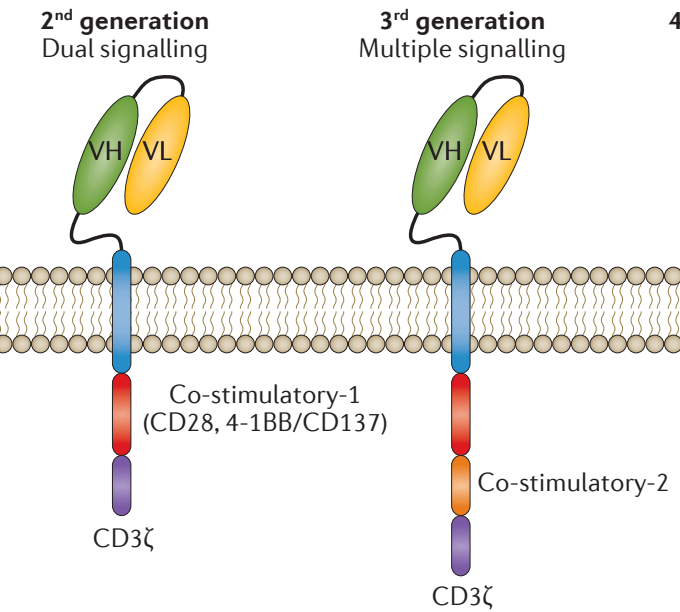

$4^{\text {th }}$ generation

(armoured)

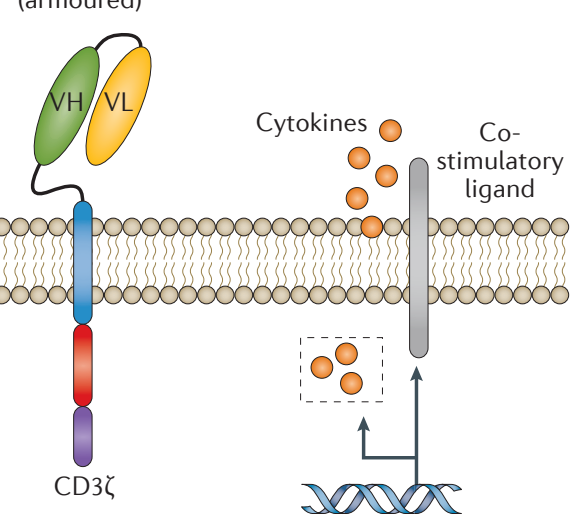

- Cytokine transgene

- Co-stimulatory ligand

transgene 
even in a post-allogeneic-HSCT setting, without the induction of graft-versus-host-disease (GVHD) $)^{49,51,52}$.

In the aforementioned studies, persistence of CAR $\mathrm{T}$ cells varied considerably. CAR-T-cell expansion in vivo peaks at approximately 14 days post-infusion ${ }^{49,51,52}$. CD28-based constructs typically persist for 2-3 months, whereas $4-1 \mathrm{BB}$-based constructs can persist beyond 2 years in a small subset of patients ${ }^{49,51,52}$. Disease relapses can be associated with a lack of CAR-T-cell persistence and immune escape via a CD19-negative malignant clone, although complete remissions lasting longer than 1 year have been noted in patients even when CAR $\mathrm{T}$ cells could not be detected beyond 2 months after infusion ${ }^{49,51,52}$. The optimal length of CAR-T-cell persistence remains unknown. Future development of CAR $\mathrm{T}$ cells for the treatment of patients with B-ALL will include administration of donor-derived CAR T cells after an allogenic HSCT as maintenance therapy or salvage therapy ${ }^{56,57}$.

Chronic lymphocytic leukaemia. The role of CAR $\mathrm{T}$ cells in the treatment of chronic lymphocytic leukaemia (CLL) is evolving. Initial studies at the MSKCC in heavily pretreated patients with relapsed/refractory and bulky disease who were treated with CAR T cells without preconditioning chemotherapy demonstrated no responses ${ }^{44}$. Follow-up studies that incorporated cyclophosphamide conditioning demonstrated better results, with two of four patients achieving stable disease (SD), one patient achieving a CR and one achieving a partial response $(\mathrm{PR})^{44,58}$. Currently, CAR T cells are being studied as consolidative therapy for patients with MRD following frontline chemotherapy with pentostatin, cyclophosphamide and rituximab (PCR) ${ }^{59}$. Of seven patients, one patient achieved a CR, two patients

\section{Figure 2 | General structure of CAR. a |CARs are created by the fusion of a} tumour-specific scFv antibody to either the TCR-associated CD3 $\zeta$ signalling domain or another intracellular signalling domains from co-stimulatory protein receptors. The scFvs are constructed by cloning the heavy and light chain variable regions of a tumour-specific $\mathrm{mAb}$, separated by a short peptide linker, into a single polypeptide. This structure allows CARs to have the tumour specificity of BCR, and to activate T cells through TCR independently of MHC. CARs can recognize various cell-surface molecules, including proteins, carbohydrate, and glycolipid structures. $\mathbf{b} \mid$ Structure of first-generation to fourth-generation CARs. The first-generation CAR contains one intracellular signalling domain, typically with the $\mathrm{CD} 3 \zeta$ signalling domain to allow for TCR signalling. The second-generation CARs have two intracellular signalling domains: a co-stimulatory domain comprising either a CD28 or a 4-1BB signalling domain, coupled with a $\mathrm{CD} 3 \zeta$ signalling domain. This arrangement enables T-cell activation and proliferation upon antigen recognition by the scFv region of the CAR. The third-generation CARs have two co-stimulatory domains and a $\mathrm{CD} 3 \zeta$ signalling domain. The first co-stimulatory domain is either a CD28 or a 4-1BB domain, with the second co-stimulatory domain consisting of either a CD28, a 4-1BB or a OX40 domain. Fourth-generation 'armoured CAR T cells' combine a second-generation CAR with the addition of various genes, including cytokine and co-stimulatory ligands, to enhance the tumoricidal effect of the CAR T cells. $\mathbf{c |}$ Common second-generation CAR T cells. Each academic centre has developed and studied slightly different CAR constructs. Abbreviations: Baylor, Baylor College of Medicine; BCR, B-cell receptor; CAR, chimeric antigen receptor; $\mathrm{mAb}$, monoclonal antibody; MDACC, MD Anderson Cancer Center; $\mathrm{MHC}$, major histocompatibility complex; NCl, National Cancer Institute; Fred Hutchinson, Fred Hutchinson Cancer Research Center; scFv, single-chain variable fragment; TCR, T-cell receptor; UPenn, University of Pennsylvania. achieved a CR in the bone marrow, but had progressive disease in the lymph nodes, and three patients achieved a $\mathrm{PR}^{59}$. These early results published in abstract form suggested that CAR T cells might be more effective against CLL cells residing in the bone marrow compared with disease in the lymph nodes.

A pilot study at UPenn, in 14 patients with relapsed and/or refractory CLL, demonstrated an overall response rate (ORR) of 57\%, with three outcomes fully published and the remainder presented in abstracts ${ }^{45,60,61}$. Preconditioning chemotherapy varied and included fludarabine, pentostatin, cyclophosphamide, or bendamustine. In this study, CAR T cells were administered over 3 days. Six patients had detectable CAR T cells for at least 5 months, and some were detectable 3 years after infusion $^{45,60,61}$. A subsequent phase II study in patients with relapsed and/or refractory CLL, with data published in abstract form ${ }^{62}$, confirmed the initial results, although the ORR was slightly lower at 35\% among 23 evaluated patients; T-cell persistence in these patients has not been reported.

Investigators at the NCI treated four patients with CLL with preconditioning fludarabine and cyclophosphamide before CAR-T-cell infusion, and the treatment was supplemented with IL-2 to promote T-cell expansion. This approach resulted in an ORR of $75 \%{ }^{63}$. IL-2 administration was associated with more prominent toxicities, such as hypotension, fevers, fatigue, renal failure, and obtundation, that can overlap with symptoms of CRS. Elimination of IL-2 in subsequent studies resulted in similar efficacy, with an ORR of $100 \%$ in four patients (three patients with CR, and one patient with a PR) ${ }^{64}$. The duration of response (DoR) ranged from 4-22 months.

Non-Hodgkin lymphoma. The cumulative experience of CAR-T-cell therapy in patients with non-Hodgkin lymphoma (NHL) is predominantly generated in patients with diffuse large-B-cell lymphoma (DLBCL) or follicular lymphoma (FL). The NCI investigators first reported a PR lasting 32 weeks in a patient with $\mathrm{FL}^{46}$. The same group later published results from four patients with indolent lymphoma: three patients with FL and one patient with splenic marginal zone B-cell lymphoma (SMZL) ${ }^{63}$. Three patients were evaluated for response, all of whom achieved a $\mathrm{PR}^{63}$. In a subsequent study in patients with chemotherapy-refractory DLBCL, four out of seven patients achieved a CR, two achieved a PR, and one achieved SD ${ }^{64}$. In addition, one patient with low-grade NHL achieved a CR and another patient with SMZL achieved a $\mathrm{PR}^{64}$. The DoR assessed in six patients was $>12$ months. The NCI group's current approach of using a reduced dose of fludarabine and cyclophosphamide to minimize toxicity was reported to result in an ORR of $66.7 \%$, with five of eight patients responding - one with a CR and four with a $\mathrm{PR}^{65}$. In a proof-of-concept study using donorlymphocyte-derived CAR T cells, the NCI group treated patients with B-cell malignancies who relapsed after allogeneic HSCT; the patients were infused with CAR T cells generated from the PBMC of their allogeneic-stem-cell donor $^{57}$. Remarkably, no increase of GVHD was seen, and among 10 treated patients, one patient with CLL achieved 
Table 1 | Clinical efficacy of second generation CAR-T-cell therapy

\begin{tabular}{|c|c|c|c|c|c|c|c|c|}
\hline \multirow{2}{*}{$\begin{array}{l}\text { Disease and } \\
\text { treating } \\
\text { institute }\end{array}$} & \multirow{2}{*}{$\begin{array}{l}\text { Number } \\
\text { of } \\
\text { patients }\end{array}$} & \multirow[t]{2}{*}{ Conditioning therapy } & \multirow{2}{*}{$\begin{array}{l}\text { Infused CAR T-cell } \\
\text { dose }\end{array}$} & \multicolumn{4}{|c|}{ Response rate } & \multirow{2}{*}{$\begin{array}{l}\text { Survival } \\
\text { outcomes }\end{array}$} \\
\hline & & & & $\begin{array}{l}\text { ORR } \\
(\%)\end{array}$ & $\begin{array}{l}\text { CR } \\
(\%)\end{array}$ & $\begin{array}{l}\text { PR } \\
(\%)\end{array}$ & $\begin{array}{l}\text { SD } \\
(\%)\end{array}$ & \\
\hline \multicolumn{9}{|l|}{$A L L$} \\
\hline MSKCC $44,48-50$ & $\begin{array}{l}22 \\
\left(16^{\star}+6^{\ddagger}\right)\end{array}$ & $\mathrm{CY}\left(1.5-3.0 \mathrm{~g} / \mathrm{m}^{2}\right)$ & $1-3 \times 10^{6} / \mathrm{kg}$ & NA & 91 & NA & NA & $\begin{array}{l}\text { Median OS: } \\
9 \text { months }\end{array}$ \\
\hline \multirow[t]{2}{*}{ UPenn ${ }^{51}$} & $30^{\star}$ & $\begin{array}{l}\text { FLU }\left(30 \mathrm{mg} / \mathrm{m}^{2} \times 4 \text { days }\right) / \mathrm{CY}\left(500 \mathrm{mg} / \mathrm{m}^{2} \times 2 \text { days }\right): 13 \text {, } \\
\text { FLU }\left(30 \mathrm{mg} / \mathrm{m}^{2} \times 4 \text { days }\right) / \mathrm{CY}\left(300 \mathrm{mg} / \mathrm{m}^{2} \times 2 \text { days }\right): 2 \text {, } \\
\text { CY }\left(440 \mathrm{mg} / \mathrm{m}^{2} \times 2 \text { days }\right) / \mathrm{VP}\left(100 \mathrm{mg} / \mathrm{m}^{2} \times 2 \text { days): } 5 \text {, }\right. \\
\text { CVAD }\left(C Y 300 \mathrm{mg} / \mathrm{m}^{2} \mathrm{q} 12 \mathrm{~h} \times 3 \text { days, vincristine } 2 \mathrm{mg}\right. \\
\left.\text { day } 3 \text {, doxorubicin } 50 \mathrm{mg} / \mathrm{m}^{2} \text { day } 3\right): 2 \text {, CY }\left(300 \mathrm{mg} / \mathrm{m}^{2}\right. \\
\text { q12h } \times 3 \text { days or } 1,000 \mathrm{mg} / \mathrm{m}^{2} \times 1 \text { day): } 3 \text {, clofarabine } \\
30 \mathrm{mg} / \mathrm{m}^{2} \times 5 \text { days: } 1 ; \mathrm{VP}\left(150 \mathrm{mg} / \mathrm{m}^{2} \times 1 \text { day }\right) / \text { Ara-C } \\
\left(300 \mathrm{mg} / \mathrm{m}^{2} \times 1 \text { day): } 1\right.\end{array}$ & $0.76-14.96 \times 10^{6} / \mathrm{kg}$ & NA & 90 & NA & NA & NA \\
\hline & & None: 3 & & & & & & \\
\hline \multicolumn{9}{|l|}{$C L L$} \\
\hline UPenn $n^{45,60,61}$ & $\begin{array}{l}14 \\
\left(3^{\star}+11^{\ddagger}\right)\end{array}$ & $\begin{array}{l}\mathrm{FLU}\left(30 \mathrm{mg} / \mathrm{m}^{2} \times 3 \text { days }\right) / \mathrm{CY}\left(300 \mathrm{mg} / \mathrm{m}^{2} \times 3 \text { days }\right): 3 \text {, } \\
\text { pentostatin/ } / \mathrm{CY}^{\S}: 5 \text {, bendamustine }{ }^{\S}: 6\end{array}$ & $0.14-5.9 \times 10^{8}$ & 57.1 & 21.4 & 35.7 & NA & NA \\
\hline UPenn $^{62}$ & $23^{\ddagger}$ & Lymphodepleting chemotherapy & $5 \times 10^{7}$ or $5 \times 10^{8}$ & 39 & 22 & 17 & NA & NA \\
\hline $\mathrm{NCl}^{63}$ & $4^{\star}$ & $\begin{array}{l}\mathrm{FLU}\left(25 \mathrm{mg} / \mathrm{m}^{2} \times 5 \text { days }\right) / \mathrm{CY}(60 \mathrm{mg} / \mathrm{kg} \times 2 \text { days })+\text { i.v. } \\
\text { IL-2 following CAR-T-cell infusion }\end{array}$ & $0.3-3 \times 10^{7} / \mathrm{kg}$ & 75 & 25 & 50 & 25 & NA \\
\hline $\mathrm{NCl}^{64}$ & $4^{\star}$ & FLU $\left(25 \mathrm{mg} / \mathrm{m}^{2} \times 5\right.$ days $) / \mathrm{CY}(60$ or $120 \mathrm{mg} / \mathrm{kg} \times 2$ days $)$ & $1-5 \times 10^{6} / \mathrm{kg}$ & 100 & 75 & 25 & NA & NA \\
\hline MSKCC 44,58 & $\begin{array}{l}10 \\
\left(8^{\star}+2^{\ddagger}\right)\end{array}$ & $\begin{array}{l}\text { None: } 4, \text { CY-conditioning }\left(1.5 \text { or } 3 \mathrm{~g} / \mathrm{m}^{2}\right): 4 \text {, } \\
\text { BR (rituximab } 375 \mathrm{mg} / \mathrm{m}^{2} \times 1 \text { day, bendamustine } \\
90 \mathrm{mg} / \mathrm{m}^{2} \times 2 \text { days): } 2\end{array}$ & $0.4-1.0 \times 10^{7} / \mathrm{kg}$ & 20 & 10 & 10 & 20 & NA \\
\hline MSKCC 67 & $6^{\ddagger}$ & BEAM conditioning and autologous SCT & $5-10 \times 10^{6} / \mathrm{kg}$ & 100 & 100 & 0 & 0 & NA \\
\hline UPenn ${ }^{66}$ & $8^{\ddagger}$ & $\mathrm{EPOCH}, \mathrm{CY}$, bendamustine, $\mathrm{FLU} / \mathrm{CY}^{\S}$ & $\begin{array}{l}3.7-8.9 \times 10^{6} / \mathrm{kg} \\
\left(\text { median } 5.8 \times 10^{6} / \mathrm{kg}\right)\end{array}$ & 50 & 37.5 & 12.5 & 0 & NA \\
\hline $\begin{array}{l}\text { Fred } \\
\text { Hutchinson }^{88}\end{array}$ & $9^{\ddagger}$ & Lymphodepleting chemotherapy & $\begin{array}{l}2 \times 10^{5} / \mathrm{kg}, 2 \times 10^{6} / \mathrm{kg} \\
\text { or } 2 \times 10^{7} / \mathrm{kg}\end{array}$ & 66.7 & 11.1 & 55.6 & NA & NA \\
\hline
\end{tabular}

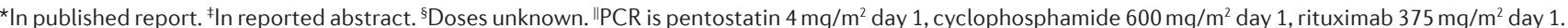
Abbreviations: ALL, acute lymphocytic leukaemia; BEAM, BCNU (carmustine) + etoposide + cytarabine + melphalan; B-NHL, B-cell non-Hodgkin lymphoma; CAR, chimeric antigen receptor; CLL, chronic lymphocytic leukaemia; CR, complete response; CVAD, cyclophosphamide + vincristine + doxorubicin + dexamethasone; CY, cyclophosphamide; EPOCH, etoposide + vincristine + doxorubicin + cyclophosphamide + prednisone; FLU, fludarabine; Fred Hutchinson, Fred Hutchinson Cancer Research Center; i.v., intravenous; MSKCC, Memorial Sloan Kettering Cancer Center; NCl, National Cancer Institute; NA, not applicable; ORR, overall response rate; OS, overall survival; PR, partial response; RFS, relapse-free survival; SD, stable disease; UPenn, University of Pennsylvania; VP, etoposide.

a CR and one patient with mantle-cell lymphoma (MCL) achieved a $\mathrm{PR}^{57}$. The omission of preconditioning chemotherapy might have contributed to the lack of significant clinical responses in this study. Nevertheless, the results successfully demonstrated the safety of donor-derived CAR T cells, infused as donor leukocyte infusions in a post-allogeneic-transplant setting.

UPenn reported preliminary phase II data, in abstract form, for patients with B-cell malignancies treated with CAR-T-cell-based therapy ${ }^{66}$. At the time of reporting,
23 patients had been enrolled, and eight were evaluable for treatment response - six patients with DLBCL and two patients with FL. The ORR at 3 months was $50 \%$, with three CR noted (in two patients with DLBCL and one patient with FL) and one PR in a patient with $\mathrm{FL}^{66}$. Four patients with DLBCL had disease progression before or at initial response assessment ${ }^{66}$. In a different strategy reported by the MSKCC group, CAR T cells was used as a consolidative therapy after autologous HSCT for patients with relapsed DLBCL, in a phase I study that 
enrolled high-risk patients with bone-marrow involvement at relapse or PET-positive disease after second-line chemotherapy ${ }^{67}$. CAR T cells are infused following conditioning with high-dose chemotherapy and autologousstem-cell infusion. Six patients have been treated on this study, with all patients achieving and maintaining a CR at a median follow up of 6 months ${ }^{67}$.

Toxicities. Adverse events associated with CAR-T-cell therapy do not necessarily correlate with the infused cell dose or timing, but are instead associated with the expansion or the persistence of the cells ${ }^{52,68}$. The most-notable toxicities related to CAR T cells are CRS, encephalopathy, and B-cell aplasia. The frequency and severity of each symptom varies greatly among different studies: CRS has been reported in $18-100 \%$ of patients, with severe CRS noted in $27-53 \%$ of patients; encephalopathy in $25-47 \%$ of patients; and B-cell aplasia, an expected on-target event, has been reported in $86-100 \%$ of patients immediately after lymphodepleting chemotherapy and CAR-T-cell infusion $^{49,51,52,64}$. B-cells commonly recovered within 6 months after aplasia, but a small number of patients had B-cell aplasia persisting for more than 1 year ${ }^{49,51,52,64}$.

CRS occurs as CAR T cells expand and induce the expression of cytokines by cells in the reactive tumour microenvironment, which can initiate a cascade of cytokine release ${ }^{49,69}$. The incidence and severity of CRS is variable after CAR-T-cell infusion, ranging from life-threatening fulminant CRS necessitating intensivecare monitoring, to laboratory-diagnosed CRS with no overt clinical symptoms. Typically, patients experience fever, tachycardia, hypotension, capillary-leak syndrome, and/or respiratory-distress syndrome, within the first 3 weeks of cell infusion ${ }^{68,69}$. A milieu of cytokines is released in patients who develop this condition, and these include IL- 6 , IFN $\gamma$, and IL- $10^{45,49,52}$. Laboratory manifestations of macrophage-activation syndrome, including cytopenias, elevated C-reactive protein (CRP) levels, marked hyperferritinaemia, and decreased fibrinogen concentrations, have been noted ${ }^{70}$. Elevated serum CRP levels, in conjunction with clinical symptoms, seems to be a biomarker of severe CRS ${ }^{49}$. Algorithms developed to aid the clinical management of CRS include administration of steroids and the IL-6-receptor-blocking antibody, tocilizumab ${ }^{49,68}$; however, steroids blunt the function of CAR T cells, whereas long-term impact of tocilizumab on CAR-T-cell function is unknown. In some series, the presence and severity of CRS correlated with the extent of disease burden at time of infusion ${ }^{49,52}$, although this observation needs to be confirmed in ongoing studies in which CAR T cells are infused during states of minimal disease.

Encephalopathy, although closely associated with CRS, is considered a distinct entity with an incidence as high as $50 \%$ in patients treated with CAR T cells ${ }^{64,71}$. Symptoms range widely, from mild confusion to obtundation, aphasia, and seizures. Cerebral spinal fluid (CSF) lymphocytosis is occasionally noted ${ }^{52}$. While most symptoms are reversible, the aetiology of these symptoms remains unclear. Many theories have been proposed, including associations with cytokine release, lymphocytosis involving CAR-T-cell penetration of the CNS, and the infused CAR-T-cell dose.

Common to all B-cell-directed therapies, B-cell aplasia has been noted in CAR-T-cell therapy owing to depletion of endogenous CD19 B lymphocytes. The duration of B-cell aplasia and its association with the persistence of CAR T cells in vivo ranges from days to years ${ }^{48,52,72}$. Intravenous immunoglobulin supplementation can help reduce the risk of opportunistic infection in patients who develop this condition; however, strategies to restore endogenous B-cell populations might be part of future investigations.

\section{Future perspectives}

Collective evidence on the use of CAR T cells indicate the following: first, second-generation CAR T cell are more efficient than first-generation CAR T cells; second, lymphodepletion by preconditioning before CAR-T-cell infusion seems necessary for successful treatment outcome and is associated with improved CAR-T-cell persistence; third, CRS is more frequently observed in patients with a high tumour burden, but can be managed with tocilizumab as well as steroids. Incorporating tumourreducing chemotherapy as well as lymphodepleting chemotherapy before CAR-T-cell infusion might improve the safety and efficacy profile of this treatment by reducing the numbers of reactive inflammatory cells in the tumour microenvironment and creating a niche for CAR-T-cell expansion and subsequent persistence ${ }^{50,51,73}$.

CAR-T-cell therapy is a promising approach, especially for transplant ineligible patients. Several challenges must be addressed, however, before CAR T cells are widely adopted in clinical practice. Identifying an ideal dose of CAR T cells is difficult because in vivo expansion of the cells is highly variable, and might predispose to inconsistency of response and unpredictable toxicity. At present, management of immune-related toxicities can be challenging. New methods to increase the safety of therapy are being evaluated and include the introduction of a suicide gene via Herpes simplex virus thymidine kinase and inducible caspase 9 (iCasp9), or targetable cell-surface proteins, such as truncated EGFR or CD20 (REFS 41,74,75).

With the success of CD19-targeted CAR T cells, targeting of other cell-specific TAAs is being explored ${ }^{76-78}$. Selective targeting of $\kappa$ or $\lambda$ light chain might reduce the incidence of B-cell aplasia and result in reduction of prolonged hypogammaglobulinaemia ${ }^{79}$. CD30-targeted and CD123-targeted CAR T cells are also being explored for potential use in treating $\mathrm{HL}^{80,81}$. Finally, incorporating chemokine or cytokine expression into the CAR-T-cell construct might improve delivery and trafficking of the cells to the tumour ${ }^{42,43,82,83}$. Combination treatment with small-molecule inhibitors, such as ibrutinib or lenalidomide, or with immune-checkpoint inhibitors can be explored to improve CAR-T-cell activation or suppress the endogenous T-cell-inhibitory microenvironment, which might enhance treatment efficacy ${ }^{84-86}$.

Relapses following treatment with CAR T cells are typically associated with a lack of T-cell persistence or the development of a CD19-negative tumour-cell 
Bispecific T-cell engager (BiTE ${ }^{\circledR}$ )

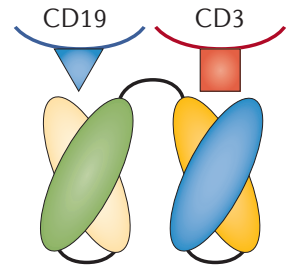

- Single polypeptide chain
Dual affinity retargeting (DART)

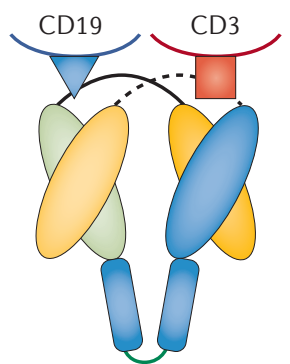

- Two polypeptide chains - Interchain disulfide bridge
Tetravalent tandem diabody (Tand $A b^{\circledR}$ )

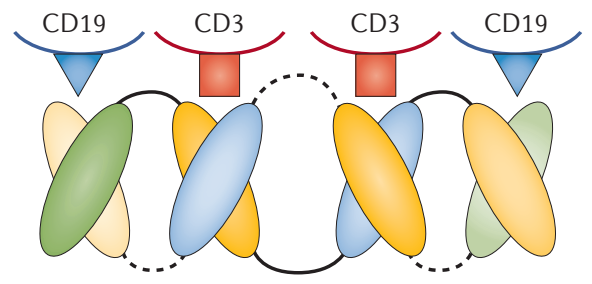

$$
\begin{aligned}
& \text { - Single polypeptide chain } \\
& \text { - Chain dimerization }
\end{aligned}
$$

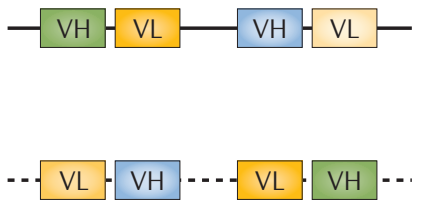

Figure 3 | Structure of different types of T-cell-engaging antibodies. BiTE ${ }^{\oplus}$ are constructed of single polypeptide chain that consists of two $V_{L}$ and $V_{H}$ pairs that recognize $C D 3$ and $C D 19$, respectively. DARTs are constructed of two separate, but paired, polypeptide chains, each comprising $V_{L}$ and $V_{H}$ regions that recognize different cell-surface molecules; the two polypeptide chains dimerize and are linked by interchain disulphide bridge, forming two functional $V_{L}-V_{H}$ pairs that each comprise a $V_{L}$ from one polypeptide and a $V_{H}$ from the other. Tand $A b^{\circledast}$ are constructed of dimerized single polypeptide chains; each chain contains two different $V_{L}$ regions and two different $V_{H}$ regions, which upon dimerization, form four antigen-recognition sites for two different antigen (two $V_{L}-V_{H}$ pairs; targeting CD19 and CD3 in this case). DARTs and Tand $A b^{\circledast}$ have longer half-life compared to BiTE ${ }^{\oplus}$ due to their structure. Abbreviations: $\mathrm{BiTE}^{\circledR}$, bispecific T-cell engagers; DART, dual affinity retargeting antibody; TandA $b^{\circledR}$, tetravalent tandem diabody; $\mathrm{V}_{\mathrm{H}}$, antibody heavy-chain variable region; $\mathrm{V}_{\mathrm{L}}$, antibody light-chain variable region.

clone $^{51,52}$. Strategies to increase the efficacy of CAR T-cells through modification of CAR constructs, such as the use of third-generation and fourth-generation armoured constructs, are being evaluated ${ }^{40}$. Another alternative approach is to infuse patients with polyspecific CAR T cells that targets multiple cell-surface proteins to prevent immune escape. Methods to increase persistence of CAR T cells to promote treatment efficacy include using allogeneic virus-specific $\mathrm{T}$ cells and a combination of CD8-positive central memory T cells and CD4-positive $\mathrm{T}$ cells ${ }^{27,87,88}$. Off-the-shelf CAR $\mathrm{T}$ cells that are matched to the recipient by HLA typing can reduce time and resource constraints of using CAR $\mathrm{T}$ cells ${ }^{89}$. Other groups have explored the possibility of downregulation of TCR to make a foundation for universal T-cell-based immunotherapy ${ }^{90}$.

On the basis of promising clinical results, multiple pharmaceutical companies (such as Novartis, Juno Therapeutics, Cellular Biomedicine Group, Bellicum, Celgene/Bluebird, Kite Pharma/Amgen, Cellectis/ Servier/Pfizer, Opus Bio, TheraVectys) are developing large-scale clinical-grade production of CAR T cells ${ }^{91}$. The participation of pharmaceutical companies is critical for success; however, the treatment is unlikely to be standardized in the near future owing to patent issues. Identification of a lead CAR-T-cell construct is unlikely in the absence of head-to-head trials that directly compare each construct and each method in specific disease settings. Results of larger studies of homogenously treated patients across multiple centres with detailed toxicity assessment will be essential in guiding the clinical development of this novel treatment strategy.

\section{Bispecific antibodies and derivatives}

Bispecific antibodies and subsequent derivatives have been developed through protein engineering of the antibody backbone to increase valency, which facilitates engagement of the immune system. The initial development of bispecific-antibody constructs faced many challenges, including immunogenicity of the product, insufficient clinical activity, and difficulties in large-scale production. Novel platforms are being developed for the treatment of lymphoid malignancies. Blinatumomab

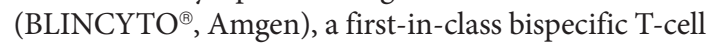
engager $\left(\mathrm{BiTE}^{\circledR}\right)$, is a $55 \mathrm{kDa}$ molecule composed of two scFv, one targeting CD19 and one against CD3, joined by a glycine-serine 5 -amino-acid non-immunogenic linker manufactured by recombinant engineering ${ }^{92,93}$. The molecule has high affinity for both CD19 and CD3, with an equilibrium dissociation constant $\left(\mathrm{K}_{\mathrm{D}}\right)$ of $10^{-9} \mathrm{M}$ and $10^{-7} \mathrm{M}$, respectively ${ }^{94}$. Similar platforms include bivalent bifunctional dual affinity retargeting antibodies (DARTs), tetravalent bifunctional tandem antibodies, and trispecific antibodies (FIG. 3).

Blinatumomab is the first drug in the bispecific antibody class to be approved by the FDA. The recombinant protein engages $\mathrm{T}$ cells via the anti-CD3 arm and creates a structurally normal immune synapse that 
targets CD1995. The functional immune synapse results in IL-2-independent polyclonal T-cell activation and apoptotic cell death of target cells ${ }^{96-98}$. Except for naive $\mathrm{T}$ cells, all CD4-positive and CD8-positive T-cell populations were found to proliferate and engage in cell lysis ${ }^{99}$. CTLs activated by blinatumomab upregulated perforin and granzyme synthesis, with eventual creation of a perforin pore at the immune synapse and discharge of toxic secretory proteins that induced apoptosis ${ }^{99}$. At doses greater than $5 \mu \mathrm{g} / \mathrm{m}^{2}$ per day, CD19-positive cells in the peripheral blood underwent apoptosis ${ }^{98}$. Calcium chelators, which inhibit T-cell signalling and the assembly of functional perforin pores, and perforin inhibitors can inhibit blinatumomab-induced cell lysis ${ }^{100}$.

Blinatumomab has a short half-life of less than $2 \mathrm{~h}^{101}$ due to its small molecular weight and the lack of a constant Fc domain that functions to stabilize antibody reserves in the body. Accordingly, this agent is administered by continuous intravenous infusion (CIV). Early dose-escalation trials in patients with NHL and CLL, in which blinatumomab was administered as a $2 \mathrm{~h}$ or $4 \mathrm{~h}$ intravenous infusion at doses ranging from $0.75-13 \mu \mathrm{g} / \mathrm{m}^{2}$ up to three times weekly, observed no objective responses ${ }^{102}$. Conversely, adverse events, especially neurological events such as aphasia, ataxia, disorientation, and seizures, were reported and resulted in treatment discontinuation in 12 patients ${ }^{102}$. As a result, all three short-term infusion trials were terminated early. Subsequent studies were designed to lengthen the mode of administration to CIV, which increased exposure to the drug and heightened treatment efficacy to an ORR of $69 \%$ in a phase I study in patients with relapsed and/or refractory NHLs of various histology ${ }^{103}$.

\section{Clinical data with blinatumomab}

Acute lymphoblastic leukaemia. CD19 is highly expressed by B-ALL, and can be targeted by blinatumomab ${ }^{104}$. In a phase II study ${ }^{105}, 21$ patients with MRD-positive ALL were treated with blinatumomab at $15 \mu \mathrm{g} / \mathrm{m}^{2}$ per day for 4 weeks per cycle - a dose that was associated with eradication of disease in the bone marrow of patients with NHL in a phase I study ${ }^{106}$. Sixteen out of 20 evaluable patients (80\%) achieved MRD-negativity, all within the first treatment cycle ${ }^{105}$. At a median follow up of 33 months, 12 patients remained in CR, resulting in a haematological relapse-free survival (RFS) rate of $61 \%{ }^{105}$. As a result of this response, 9 patients proceeded to receive allogeneic $\mathrm{HSCT}^{105}$. Among the 11 patients who did not receive allogeneic HSCT, five relapses occurred, all within 7 months of treatment ${ }^{105}$. Overall, six patients relapsed after achieving a CR, characterized as CD19-negative relapses in two patients and relapse in sites of immune privilege (CNS and testis) in another two patients ${ }^{105}$.

Following these promising results, two larger phase II studies were conducted to include ALL patients with haematological relapse (TABLE 2) ${ }^{107,108}$. The first study varied from the phase I study in terms of the preconditioning regimen used and deployed step-up dosing of blinatumomab from $5-30 \mu \mathrm{g} / \mathrm{m}^{2}$ per day to optimize outcome while minimizing occurrence of CRS and neurological toxicities ${ }^{107}$. In total, 25 of 36 patients (69\%) achieved a CR or CRh (CR with a partial recovery of peripheral blood counts); the median RFS was 7.6 months, and the median overall survival was 9.8 months ${ }^{107}$. The relapsed cases included both CD19-positive and CD19-negative phenotypes ${ }^{107}$. A larger multicentre study ${ }^{108}, 189$ patients with Ph-negative relapsed/refractory B-ALL were treated with $9 \mu \mathrm{g}$ per day of blinatumomab for the first week, and at an escalated dose of $28 \mu \mathrm{g}$ per day for weeks 2-4 by CIV. Preconditioning with dexamethasone was required for these patients with high-volume disease; of these, 81 (43\%) achieved a CR or CRh (CR $33 \%$, CRh 10\%) within the first two treatment cycles. The median overall survival and RFS were 6.1 months after a median follow-up of 9.8 months, and 5.9 months after a median follow-up of 8.9 months, respectively. Patients with less than $50 \%$ blasts in their bone marrow at baseline evaluation had a higher CR or CRh rate. No other subgroup had a differential response to treatment.

Table 2 | Clinical efficacy of blinatumomab

\begin{tabular}{|c|c|c|c|c|c|c|c|c|}
\hline \multirow[t]{2}{*}{ Disease } & \multirow{2}{*}{$\begin{array}{l}\text { Number } \\
\text { of } \\
\text { patients }\end{array}$} & \multirow[t]{2}{*}{ Treatment schedule } & \multicolumn{4}{|c|}{ Response rate } & \multirow{2}{*}{$\begin{array}{l}\text { Relapse- } \\
\text { free } \\
\text { survival }\end{array}$} & \multirow{2}{*}{$\begin{array}{l}\text { Median } \\
\text { overall } \\
\text { survival }\end{array}$} \\
\hline & & & ORR (\%) & CR (\%) & PR (\%) & SD (\%) & & \\
\hline $\begin{array}{l}\text { MRD-positive } \\
\text { ALL }{ }^{105,106}\end{array}$ & $20^{*}$ & $\begin{array}{l}15 \mu \mathrm{g} / \mathrm{m}^{2} \text { per day continuous i.v. } \times 4 \text { weeks } \\
\text { every } 6 \text {-week cycle }\end{array}$ & NA & 80 & NA & NA & $\begin{array}{l}61 \% \text { at } \\
33 \text { months }\end{array}$ & NA \\
\hline $\mathrm{ALL}^{107}$ & $36^{*}$ & $\begin{array}{l}5 \mu \mathrm{g} / \mathrm{m}^{2} \text { and } 15 \mu \mathrm{g} / \mathrm{m}^{2} \text { per day (week } 1 \text {, } \\
\text { and thereafter until } 4 \text { weeks, respectively) }\end{array}$ & NA & 69 & NA & NA & $\begin{array}{l}\text { Median of } \\
7.6 \text { months }\end{array}$ & 9.8 months \\
\hline $\mathrm{ALL}^{108}$ & $189^{*}$ & $\begin{array}{l}9 \mu \mathrm{g} \text { and } 28 \mu \mathrm{g} \text { per day (week } 1 \text {, and } \\
\text { thereafter, respectively) continuous i.v. } \\
\times 4 \text { weeks every } 6 \text {-week cycle }\end{array}$ & NA & 43 & NA & NA & $\begin{array}{l}\text { Median of } \\
5.9 \text { months }\end{array}$ & 6.1 months \\
\hline $\begin{array}{l}\text { B-NHL (FL, } \\
\text { MCL, DLBCL) })^{103}\end{array}$ & $35^{\ddagger}$ & $60 \mu \mathrm{g} / \mathrm{m}^{2}$ per day continuous i.v. & 69 & 37 & 32 & NA & NA & NA \\
\hline $\mathrm{DLBCL}^{109}$ & $21^{\ddagger}$ & $\begin{array}{l}\text { Cohort I and III: } 9 \mu \mathrm{g}, 28 \mu \mathrm{g} \text {, and } 112 \mu \mathrm{g} \\
\text { per day (week } 1 \text {, week } 2 \text {, and thereafter, } \\
\text { respectively), cohort II: } 112 \mu \mathrm{g} \text { per day } \\
\times 8 \text { weeks }\end{array}$ & 43 & 19 & 23.8 & NA & NA & NA \\
\hline
\end{tabular}

*In published report. ${ }^{\ddagger}$ In reported abstract. Abbreviations: ALL, acute lymphocytic leukaemia; B-NHL, B-cell non-Hodgkin lymphoma; CR, complete response; DLBCL, diffuse large-B-cell lymphoma; FL, follicular lymphoma; i.v., intravenous; MCL, mantle-cell lymphoma; MRD, minimal residual disease; NR, not applicable or available; ORR, overall response rate; PR, partial response; SD, stable disease. 
Non-Hodgkin lymphoma. Patients with relapsed/refractory indolent lymphoma were treated with CIV of blinatumomab at $0.5-90 \mu \mathrm{g} / \mathrm{m}^{2}$ per day, with the maximum tolerated dose identified as $60 \mu \mathrm{g} / \mathrm{m}^{2}$ per day ${ }^{98}$. The study subsequently included patients with DLBCL, and 76 patients in total received treatment. The histological subtypes were defined as $37 \% \mathrm{FL}, 32 \% \mathrm{MCL}, 18 \%$ DLBCL, and $13 \%$ other indolent lymphomas ${ }^{103}$. Clinical responses were seen above doses of $15 \mu \mathrm{g} / \mathrm{m}^{2}$ per day. Among the patients treated at $60 \mu \mathrm{g} / \mathrm{m}^{2}$ per day $(n=35)$, the ORR across NHL subtype was $69 \%$, with a CR rate of $37 \%$ (TABLE 2), and a median DoR of 404 days ${ }^{103}$. Patients with FL had the highest ORR at $80 \%$, followed by $71 \%$ in patients with MCL, and 55\% in those with DLBCL ${ }^{103}$. A phase II study of blinatumomab is currently enrolling patients with relapsed/refractory DLBCL ${ }^{109}$; patients will be treated at either a weekly step-up dose of $9 \mu \mathrm{g}$ per day, $28 \mu \mathrm{g}$ per day, and $112 \mu \mathrm{g}$ per day or a fixed-dose of $112 \mu \mathrm{g}$ per day for 8 weeks, and all patients will receive dexamethasone as prophylaxis for CRS. To date, 25 patients have been enrolled, and the ORR among 21 evaluable patients was $43 \%$, including four CRs (19\%), and five PRs (23.8\%).

Toxicity. Most adverse events experienced in the phase I study of blinatumomab were mild-to-moderate, and were reversible; however, neurological toxicities that included headache, tremor, aphasia, ataxia, disorientation and seizure, as well as infection associated with leukopenia and neutropenia, raise concern ${ }^{102}$. Subsequent studies explored various CIV dosing schedules and preconditioning strategies to minimize toxicities. Fewer than $10 \%$ of patients in each study experienced grade $\geq 3$ CRS. Neurological events were reversible, and were managed with either dexamethasone administration or treatment interruption in a limited number of cases ${ }^{105-108}$. Overall, $10 \%$ of patients discontinued blinatumomab treatment owing to therapy-related toxicities ${ }^{105-108}$. Nevertheless, caution and awareness of neurological toxicity remains imperative in the management of these patients. Steroids can limit T-cell proliferation, which is a concern in the case of treatment with CAR T cells, but dexamethasone showed no impact on treatment efficacy of blinatumomab $^{108}$. Other common adverse effects seen in the phase II studies of blinatumomab were fever, fatigue, headache, tremor, leukopenia, hypokalemia, decrease of blood immunoglobulin, febrile neutropenia, and anae$\mathrm{mia}^{105-109}$; severe adverse events included infections, and CNS and psychiatric disorders. Transient B-cell aplasia and resulting hypogammaglobulinaemia have been reported in patients treated with blinatumomab ${ }^{110}$.

Predictive markers of neurological adverse events of blinatumomab have been explored. A low B cell: T cell ratio in the peripheral blood was associated with an increased risk of CNS toxicity in patients with NHL ${ }^{111}$. Presumably, circulating B-cells act as a sink to stimulate T-cell proliferation in the peripheral blood before the drug triggered a similar response in the $\mathrm{CNS}^{102}$. Patients with high $B$ cell: $T$ cell ratio were successfully treated with a fixed dose of $60 \mu \mathrm{g} / \mathrm{m}^{2}$ per day without major CNS complications, whereas patients with a lower B cell:T cell ratio benefited from step-up dosing of blinatumomab ${ }^{11,112}$.

\section{Future perspectives}

Blinatumomab was approved for the treatment of relapsed and/or refractory B-ALL by the FDA in December 2014. The cumbersome administration schedule is driving ongoing improvements of this treatment platform. The $\mathrm{BiTE}^{\circledR}$ concept relies on a scFv linked by a short flexible polypeptide linker allowing the $\mathrm{V}_{\mathrm{H}}$ and $\mathrm{V}_{\mathrm{L}}$ domains to interact preferentially with more-distant molecules. Manipulation of the structure, valency, and stability, via Fc expression or protein conjugation through protein engineering, have generated therapies such as DARTs and tandem antibody-based therapies.

DARTs are encoded by two paired polypeptides, each composed of the $\mathrm{V}_{\mathrm{L}}$ of the scFV targeting one antigen in tandem with the $\mathrm{V}_{\mathrm{H}}$ of the scFV targeting the other antigen, connected by a shorter linker that does not allow for intrachain interaction (FIG. 3) ${ }^{113}$. A covalent disulphide bond formed between cysteines at the $C$-termini of the polypeptides stabilizes the complex of the two Fv chains. In comparison to $\mathrm{BiTE}^{\circledR}$, DARTs have longer in vitro halflife, while maintaining effective cytotoxicity and capacity of B-cell lysis ${ }^{114}$. Tandem diabodies (Tand Ab ${ }^{\circledR}$ ) are composed of four variable domains expressed in one long polypeptide, which are connected by linkers of varying lengths that direct complementary dimerization to form tetravalent bispecific antibodies or diabody folding to form bivalent bispecific antibodies ${ }^{115}$. The efficiency of $\mathrm{Tand}_{\mathrm{Ab}}{ }^{\circledR}$ formation is dependent on the linker length, but this structure offers the potential for higher avidity from bivalency for each target. Production strategies include bacterial expression systems that require a refolding step to generate functional molecules, or mammalian recombinant protein expression, which doesn't require this additional step but is more costly. Methods to further stabilize diabodies (such as DARTs and Tand $A b^{\circledR}$ ) include covalent linkage, PEGylation, $N$-glycosylation, introduction of an Fc fragment, or direct fusion to albumin ${ }^{116,117}$.

The design of bispecific antibodies requires a balance of features that include bioavailability, target affinity, stability, and efficacy. Attempts to modify the bispecific-antibody platforms should improve bioavailability and mitigate the inconvenient continuous dosing requirement (FIG. 3). Incorporation of an Fc domain greatly increases bioavailability, but might hinder production. Increasing valency, as in Tand $\mathrm{Ab}^{\circledR}$, potentially improves the affinity and stability of bispecific antibodies. However, because affinity, stability and efficacy are independent parameters, efficacy may not be evident until late stages of clinical development. Clinical developments incorporating these novel platforms are under way, and include a Tand $A b^{\circledR}$ that recognizes CD30 and CD16A and is being tested in patients with HL (NCT01221571) $)^{118}$.

\section{Immune-checkpoint inhibitors}

The immune-checkpoint axis serves to maintain selftolerance and prevent autoimmunity ${ }^{119}$. The immune synapse formed between antigen-presenting cells (APCs) and $\mathrm{T}$ cells is controlled by many co-stimulatory and inhibitory interactions that modulate the intensity and duration of T-cell responses initiated through the TCR 


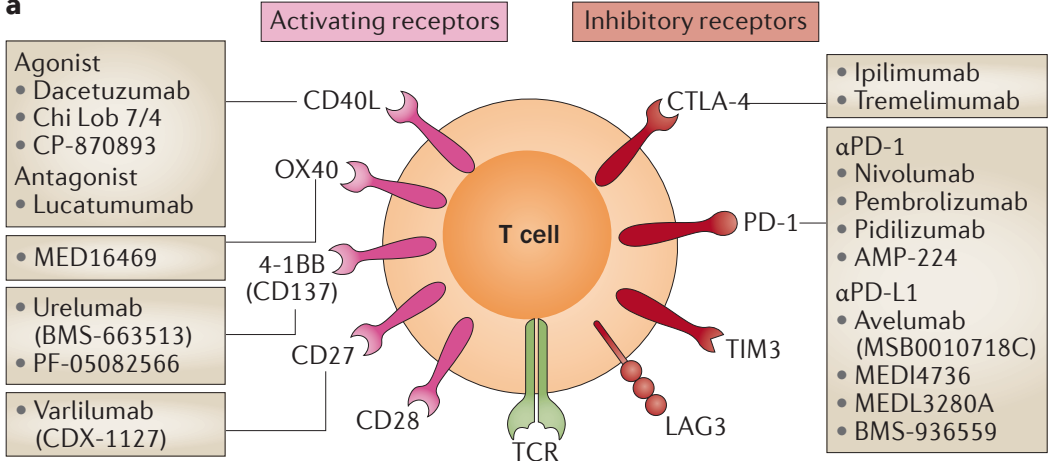

Agonistic antibodies

b
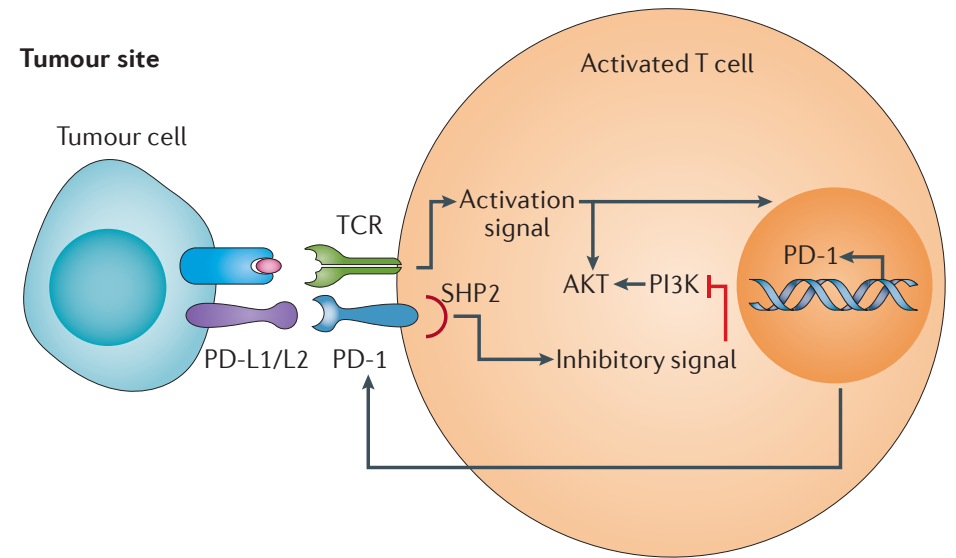

Lymph node presenting cell

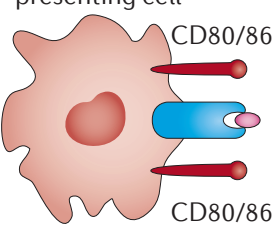

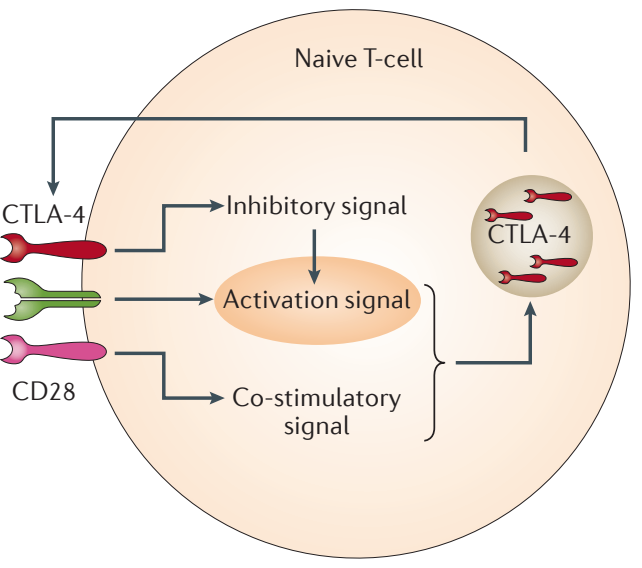

(FIG. 4a). Tumour and/or nontumour cells from the surrounding microenvironment commonly overexpress inhibitory proteins that suppress T-cell-effector functions, such as cytotoxic T-lymphocyte-associated-protein 4 (CTLA-4) and programmed cell-death protein 1 (PD-1), leading to immune escape of the tumour ${ }^{119-122}$. The discovery that inhibition of CTLA-4 dampened tumour growth in mouse models provided the first clue that modulation of immune checkpoints might be a viable therapeutic strategy ${ }^{123}$. Since this discovery, blockade of CTLA-4 and PD-1 pathways has changed the management of several solid cancers. Antagonistic antibodies targeting immune-inhibitory signals and agonist antibodies targeting immune-activating signals are currently being explored for the treatment of cancer, including lymphoid malignancies.
Figure 4 | The immune-checkpoint axis that serves to maintain self-tolerance and prevent autoimmunity.

a | Components of the immune synapse. T cells recognize antigens presented on the MHC by the TCR. The fate of T cells upon antigen recognition is determined by the additional ligand-receptor interactions between the T cells and APCs (or tumour cells). The co-stimulatory signals activated via CD28, 4-1BB (CD137), OX40, and CD27 promote activation of T cells, whereas those sent via CTLA-4 and PD-1 decrease T-cell activation. Various treatment modalities are being developed to modulate these signals. Antagonistic antibodies have been developed that target co-stimulatory signals delivered via OX40OX40L, 4-1BB (CD137)-4-1BBL (CD137L), and CD27CD70 interaction. Both agonistic and antagonistic antibodies that target the CD40-CD40L interaction are in development. Immune-checkpoint inhibitors target the inhibitory signals transduced through the PD-1PD-L1 axis and CTLA-4 interactions. Molecules engaged in co-stimulatory signalling are coloured in pink, and those involved in inhibitory signalling are coloured in red. $\mathbf{b}$ | Mechanism of T-cell activation at the tumour site and the lymph node. APCs take up TAAs at the site of tumour. The APCs migrate to the lymph node, where they present the TAA to naive (inactive) T cells. The specific $T$ cells that recognize the TAA are activated (primed) via TCR-mediated signalling as well as co-stimulation through CD28 and CD80 and/or CD86 interactions. T-cell activation is interrupted when CTLA-4 is mobilized to the cell surface from intracellular stores and competes with CD28 for interaction with CD80 and CD86. The activated (primed) T cells circulate to the peripheral tissues and organs, and will be reactivated upon re-challenge with the TAA at the tumour site. Activation of T cells in the periphery is decreased upon expression of PD-1 on the surface of activated $T$ cells after its transcriptional activation and engagement with its ligand PD-L1/PD-L2 that can be expressed on the tumour cells or on other immune cells in the tumour microenvironment. Abbreviations: APC, antigen-presenting cell; CTLA-4, cytotoxic T-lymphocyte-associated protein 4; MHC, major histocompatibility complex; PD-1, programmed cell death protein 1; PD-L1, programmed cell death 1 ligand 1; PD-L2, programmed cell death 1 ligand 2; TAA, tumour-associated antigen; TCR, T-cell receptor.

Although CTLA-4 and PD-1 both exhibit inhibitory effects on tumour immunity, their mechanisms of action are distinct (FIG. 4b). CTLA-4 is predominantly expressed on T cells in the lymph nodes, where the cells are initially activated by APCs. Activation of T cells via TCR signalling and CD28 co-stimulation mobilizes the intracellular pool of CTLA-4 to relocate to the cell surface ${ }^{124}$, where CTLA- 4 can bind to its ligands CD80 and CD86 and mediate signalling that terminates CD28 co-stimulation and T-cell activation ${ }^{125,126}$. By contrast, PD-1 predominantly functions in activated $\mathrm{T}$ cells in the periphery upon recognition of its ligands on tumour cells (or other host cell types); activation of T cells leads to transcriptional activation of PD-1 and its expression on the cell surface, and subsequent engagement of PD-1 with its ligands PD-L1 or PD-L2 antagonizes PI3K activity, 
leading to the blockade of T-cell activation (FIG. 4b) ${ }^{127}$. In mice, phenotypes resulting from inactivation of PD-1 or its ligands are usually mild, consisting of late-onset, organ-specific inflammation ${ }^{128-130}$. By contrast, CTLA-4 knockout mice succumb to a lethal multiorgan lymphoproliferative disease ${ }^{131,132}$. These phenotypic differences possibly correlate with the range of toxicities that are seen clinically with the anti-CTLA- 4 and anti-PD-1 blocking antibodies.

Targeting the PD-1-PD-L1 axis in patients with haematological malignancies has attracted attention because of the frequent expression of PD-L1 and/or $\mathrm{PD}-\mathrm{L} 2$ in various lymphoid malignancies ${ }^{133-135}$. PD-L1 is expressed on haematopoietic cells, such as T cells, $B$ cells, macrophages, natural killer cells, and dendritic cells, as well as on nonhaematopoietic cells ${ }^{136}$. The mechanisms that lead to PD-L1 and/or PD-L2 overexpression in patients with haematological malignancies are varied, including genetic alterations or activation of JAK/STAT signalling pathways in some cases, as well as in response to cytokine stimuli, such as IFN $\gamma^{133,137-139}$. PD-L1 is frequently expressed in Hodgkin Reed-Sternberg cells through chromosome translocation, gene amplification, and EBV-related mechanism ${ }^{133,137,140}$. In the setting of NHL, PD-L1 is expressed in various histologies including DLBCL, primary mediastinal large-B-cell lymphoma (PMBL), and anaplastic large-cell lymphoma ${ }^{134,135}$. In patients with PMBL, gene fusions place the genes encoding $\mathrm{PD}-1$ ligands under the regulation of MHC class II transactivator (CIITA), resulting in their aberrant expression. In patients with HL, amplification of chromosome 9p23-24 (where the genes encoding PD-L1 and PD-L2 reside) is frequently observed ${ }^{140,141}$. At the present time, clinical experience with immunecheckpoint inhibition in patients with lymphoma is limited to antibodies targeting PD-1 (pidilizumab, pembrolizumab, nivolumab) and CTLA-4 (ipilimumab); however, interest in targeting components of the co-stimulatory pathway, such as $4-1 \mathrm{BB}$ and $\mathrm{OX} 40$, is growing. Indeed, agonist antibodies against $4-1 \mathrm{BB}$ and OX40 are in various stages of clinical development.

\section{Clinical data on immune-checkpoint inhibition}

Non-Hodgkin lymphoma. Pidilizumab was the first PD-1 blocking antibody to be tested in patients with lymphoid malignancies. Data from phase I and phase II studies of pidilizumab in patients with DLBCL, and in combination with rituximab in patients with relapsed/refractory FL, showed promising results ${ }^{142-144}$; however, pidilizumab is considered to have low specificity for PD-1. Nivolumab and pembrolizumab are also being evaluated in patients with various haematological malignancies, including NHL. In a recent phase I study of nivolumab (TABLE 3), 31 patients with B-cell lymphoma were included ${ }^{145}$. Among 29 patients, excluding two patients with PMBL, eight patients (28\%) had an objective response, including three patients with a $\mathrm{CR}$ and five patients with a $\mathrm{PR}^{145}$. The response rate was highest in patients with FL, in whom the ORR was $40 \%{ }^{145}$. Patients with DLBCL had an ORR of $36 \%$, including two patients with a CR and two patients with a $\mathrm{PR}^{145}$. This study also included patients with T-cell lymphoma ( $n=23)$, including 13 patients with mycosis fungoides and five patients with peripheral T-cell lymphoma (PTCL) ${ }^{145}$. The ORR for these patients was $17 \%$, with four patients (17\%) achieving a $\mathrm{PR}^{-}$two patients with mycosis fungoides and two with PTCL ${ }^{145}$. A phase I study of pembrolizumab in patients with NHL is currently ongoing (NCT01953692) ${ }^{146,147}$.

Hodgkin lymphoma. Phase I studies of both nivolumab and pembrolizumab have demonstrated exciting results in patients with HL (TABLE 3). Nivolumab given at $1 \mathrm{mg} / \mathrm{kg}$ or $3 \mathrm{mg} / \mathrm{kg}$ in weeks 1 and 4, and then every 2 weeks thereafter until disease progression showed an ORR of $87 \%$ in 23 patients: six (26\%) had a CR, $14(61 \%)$ had a PR ${ }^{145,148}$. Additionally, three (13\%) patients had $\mathrm{SD}^{148}$. The progression-free survival rate at 24 weeks was $86 \%{ }^{148}$. The patients included in this study were heavily pretreated with $87 \%$ having received three or more prior treatments, $78 \%$ had received brentuximab vedotin, and $78 \%$ had undergone autologous $\mathrm{HSCT}^{148}$. Nivolumab was active in all patients regardless of their prior treatment status ${ }^{148,149}$. In a separate phase I study, pembrolizumab was also evaluated for efficacy and safety in patients with relapsed/refractory $\mathrm{HL}^{150}$. All patients had prior exposure to brentuximab vedotin, and $69 \%$ of the patients had received autologous $\mathrm{HSCT}^{150}$. Among 29 evaluable patients, the ORR was $63 \%$, including six patients with CR, and 13 patients with $\mathrm{PR}^{150}$. Six patients obtained $\mathrm{SD}^{150}$. With a median observation period of 153 days, the median DoR had not been reached (range 1-185 days) ${ }^{150}$. Both of these studies have evaluated the expression of PD-L1 and/or PD-L2 in the tumour cells in patients with available samples, and showed PD-L1 and/or PD-L2 expression by the malignant Reed-Sternberg cells in all cases ${ }^{148,150}$.

Other immune-checkpoint-targeting antibodies in development include anti-PD-L1 and anti-4-1BB antibodies. Anti-PD-L1 antibodies have been developed and are currently being tested in patients with various cancers including NHL (NCT02220842) ${ }^{151,152}$. Urelumab is an antibody to $4-1 \mathrm{BB}$ that is currently being evaluated in a clinical trial in combination with rituximab (NCT01775631) ${ }^{153}$. Ipilimumab has been evaluated for efficacy in a pilot study in patients with NHL who relapsed following allogeneic HSCT ${ }^{154}$. The treatment was relatively safely administered, with no cases of grade 3 or 4 GVHD observed following ipilimumab treatment, although two patients developed organspecific immune-related adverse events, both involving the lung ${ }^{154}$. Two patients $(14.3 \%)$ achieved CR to ipilimumab and another two patients had $\mathrm{SD}^{154}$.

Toxicity. Toxicities related to immune-checkpoint inhibitors are typically immune-related and include pneumonitis, colitis, hepatitis, hypophysitis, and thyroiditis ${ }^{155}$. The frequency and severity of these adverse effects vary depending on the antibody, pathway, and disease. On the basis of the abundant experience of immune-checkpoint inhibitors in solid tumours, the occurrence of grade 3-4 immune-related adverse events is approximately $20 \%$ with ipilimumab, compared with 5-10\% with nivolumab or pembrolizumab ${ }^{156}$. In general, PD-1 blockade is associated 
Table 3 | Clinical efficacy of immune-checkpoint inhibitors

\begin{tabular}{|c|c|c|c|c|c|c|c|c|}
\hline \multirow{2}{*}{$\begin{array}{l}\text { Drug } \\
\text { (manufacturer) } \\
\text { and disease }\end{array}$} & \multirow{2}{*}{$\begin{array}{l}\text { Number } \\
\text { of } \\
\text { patients }\end{array}$} & \multirow[t]{2}{*}{ Treatment schedule } & \multicolumn{4}{|c|}{ Response rate } & \multirow{2}{*}{$\begin{array}{l}\text { Median } \\
\text { duration of } \\
\text { response } \\
\text { (range) }\end{array}$} & \multirow[t]{2}{*}{ Survival outcomes } \\
\hline & & & $\begin{array}{l}\text { ORR } \\
(\%)\end{array}$ & $\begin{array}{l}\text { CR } \\
(\%)\end{array}$ & $\begin{array}{l}\text { PR } \\
(\%)\end{array}$ & $\begin{array}{l}\text { SD } \\
(\%)\end{array}$ & & \\
\hline B-NHL ${ }^{145 *}$ & $31^{\ddagger}$ & $\begin{array}{l}1 \mathrm{mg} / \mathrm{kg} \text { or } 3 \mathrm{mg} / \mathrm{kg} \text { week } 1 \text {, week } 4 \text {, } \\
\text { and every } 2 \text { weeks thereafter }\end{array}$ & 26 & 10 & 16 & 52 & NA & NA \\
\hline $\operatorname{DLBCL}^{145 *}$ & $11^{\ddagger}$ & $\begin{array}{l}1 \mathrm{mg} / \mathrm{kg} \text { or } 3 \mathrm{mg} / \mathrm{kg} \text { week } 1 \text {, week } 4 \text {, } \\
\text { and every } 2 \text { weeks thereafter }\end{array}$ & 36 & 18 & 18 & 27 & $\begin{array}{l}22 \text { weeks } \\
\text { (6-77 weeks) }\end{array}$ & NA \\
\hline $\begin{array}{l}\text { Follicular } \\
\text { lymphoma }^{145 *}\end{array}$ & $10^{\ddagger}$ & $\begin{array}{l}1 \mathrm{mg} / \mathrm{kg} \text { or } 3 \mathrm{mg} / \mathrm{kg} \text { week } 1 \text {, week } 4 \text {, } \\
\text { and every } 2 \text { weeks thereafter }\end{array}$ & 40 & 10 & 30 & 60 & $\begin{array}{l}\text { Not reached } \\
\text { (27-82 weeks) }\end{array}$ & NA \\
\hline T-NHL ${ }^{145}$ & $23^{\ddagger}$ & $\begin{array}{l}3 \mathrm{mg} / \mathrm{kg} \text { week } 1 \text {, week } 4 \text {, and every } \\
2 \text { weeks thereafter }\end{array}$ & 17 & 0 & 17 & 43 & NA & NA \\
\hline $\begin{array}{l}\text { Hodgkin } \\
\text { lymphoma }\end{array}$ & $23^{\S}$ & $\begin{array}{l}1 \mathrm{mg} / \mathrm{kg} \text { or } 3 \mathrm{mg} / \mathrm{kg} \text { week } 1 \text { and } 4 \text {, } \\
\text { and every } 2 \text { weeks thereafter }\end{array}$ & 87 & 26 & 61 & 13 & NA & $\begin{array}{l}\text { PFS: } 86 \% \text { at } 24 \text { weeks } \\
\text { OS: median not reached }\end{array}$ \\
\hline \multicolumn{9}{|c|}{ Ipilimumab (BMS, USA) } \\
\hline B-NHL ${ }^{154}$ & 18 & $\begin{array}{l}3 \mathrm{mg} / \mathrm{kg} \rightarrow 1 \mathrm{mg} / \mathrm{kg} \times 3 \text { doses } \\
\text { (or } 3 \mathrm{mg} / \mathrm{kg} \times 4 \text { doses in } 6 \text { patients) }\end{array}$ & 11.1 & 5.6 & 5.6 & NA & NA & NA \\
\hline 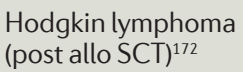 & $14^{\S}$ & $0.1-3.0 \mathrm{mg} / \mathrm{kg}$ & 14.3 & 14.3 & 0 & 14.3 & NA & NA \\
\hline
\end{tabular}

with fewer and less-severe toxicities compared with CTLA-4 blockade. Combination immune-checkpoint blockade with nivolumab and ipilimumab substantially increased the occurrence of grade $\geq 3$ treatment-related adverse events to over $50 \%$, with $45 \%$ patients not completing all doses of therapy ${ }^{157}$. Immune-related toxicities can be managed with immune-modulating agents, including corticosteroids and infliximab. An algorithm for managing CTLA-4 blockade has been developed to ease the difficulties in managing these patients and a similar approach is used for anti-PD-1 agents ${ }^{158}$.

Although experience in patients with lymphoid malignancies is limited, immune-related toxicities of immune-checkpoint therapy seem to be similar to those observed in patients with solid tumours. Pidilizumab therapy in patients with haematological cancer resulted in no immune-related adverse events, and the most frequent grade 3 to 4 adverse effects were neutropenia (19\%) and thrombocytopenia (8\%), which might have been related to preceding autologous HSCT ${ }^{142-144}$. Among patients with lymphoma treated with nivolumab, the mostcommon adverse events were rash (22\%), decreased platelet count $(17 \%)$, fatigue $(13 \%)$, and pneumonitis (11\%); drug-related grade $\geq 3$ toxicities, including acute respiratory distress syndrome, pneumonitis, and sepsis, were observed in $21 \%$ of patients ${ }^{148,159}$. Clinical experience of pembrolizumab in patients with lymphoma is currently limited to a small number of patients with relapsed HL. The most frequent adverse events seen in this population were hypothyroidism and pneumonitis, both observed in three (10\%) patients. Three patients experienced four grade 3 treatment-related toxic effects, which included axillary pain, hypoxia, joint swelling, and pneumonitis ${ }^{150}$.

\section{Future perspectives}

Targeting the PD-1-PD-L1 axis in patients with lymphoid malignancies is a promising treatment strategy, especially for those with HL. Larger-scale studies are necessary to confirm the efficacy of these drugs. Phase II studies of nivolumab as a single agent against relapsed and/or refractory FL, DLBCL, and Hodgkin lymphoma are ongoing (NCT02038946, NCT02038933, NCT02181738) (160-162. $^{\text {. }}$ The observed responses are rarely CRs supporting the rational combination of immune-checkpoint therapies with other agents to improve the quality of response and response duration. Several combination studies are currently being conducted, including combinations with other immune-checkpoint inhibitors, such as ipilimumab $(\mathrm{NCT} 01592370)^{163}$.

Substantial effort has been invested in finding predictive biomarkers of response to these agents. Experience with solid tumours indicates the utility of PD-L1 expression, mutational load, and T-cell infiltration of the tumours as potential predictive factors of response ${ }^{164-168}$; however, the utility of these biomarkers have not been validated in lymphoid malignancies. Of note, the baseline landscape of somatic mutations in lymphoid malignancies remain low compared with solid tumours, and the frequent loss of MHC class I/II expression in $\mathrm{HL}$ poses an interesting question as to the mechanism 
of T-cell activation in these tumours. Further efforts should be made to understand the biology underlying these responses ${ }^{169-171}$.

\section{Conclusions}

We are entering an exciting era of immunotherapies for lymphoid malignancies. Promising results with CAR $\mathrm{T}$ cells, bispecific antibodies and their derivatives, and immune-checkpoint blockade have been demonstrated, and without doubt, immunotherapies will become one of the central components of treatment strategies in lymphoid malignancies, especially in the relapsed and/or refractory setting. Despite the excitement, several issues remain to be overcome, including technical engineering, especially of CAR-T-cell therapies and bispecific antibodies. Compared with the astounding result of both CAR-T-cell therapy and bispecific antibodies in the treatment of ALL, the results seen in patients with NHL and CLL are somewhat less striking but remain promising; this inconsistency might in part be due to the immunosuppressive microenvironment associated with these tumours, although further investigation is necessary to explain this difference in efficacy.
In addition to further exploration of efficacy, we will need to understand in granular detail the mechanism of actions of each treatment modality to better manage and sequence each treatment option for our patients. Thus far, head-to-head comparison studies have not been performed, which precludes comparisons between treatment modalities. Each platform has its own strengths and weaknesses. For example, the similar mechanism of action of blinatumomab and CD19-targeted CAR T cells present a similar toxicity profile. CIV administration of blinatumomab is inconvenient, although the short half-life of this agent is advantageous in that it enables rapid titration of the drug to minimize toxicity. The in vivo persistence and expansion of CAR T cell results in a variable dose-effect relationship across patients; however, the longevity of the T cells might provide long-term disease control. Anti-PD-1 antibodies have shown remarkable efficacy against HL, but combination treatments will be needed to improve CR rates. The results of ongoing and future studies will enable us to understand the differential use of these treatments as a single or a combined modality that improves the prognosis of patients.
1. Horowitz, M. et al. Graft-versus-leukemia reactions after bone marrow transplantation. Blood 75 , 555-562 (1990).

2. Maloney, D. G. et al. IDEC-C2B8: results of a phase I multiple-dose trial in patients with relapsed nonHodgkin's lymphoma. J. Clin. Oncol. 15, 3266-3274 (1997).

3. Maloney, D. G. et al. IDEC-C2B8 (rituximab) anti-CD20 monoclonal antibody therapy in patients with relapsed low-grade non-Hodgkin's lymphoma. Blood 90, 2188-2195 (1997).

4. Coiffier, B. et al. CHOP chemotherapy plus rituximab compared with $\mathrm{CHOP}$ alone in elderly patients with diffuse large-B-cell lymphoma. N. Engl. J. Med. 346 , 235-242 (2002)

5. Doubrovina, E. et al. Adoptive immunotherapy with unselected or EBV-specific T cells for biopsy-proven $\mathrm{EBV}+$ lymphomas after allogeneic hematopoietic cel transplantation. Blood 119, 2644-2656 (2012).

6. Chapuis, A. G. et al. Transferred WT1-reactive CD8 + $\mathrm{T}$ cells can mediate antileukemic activity and persist in post-transplant patients. Sci. Transl. Med. 5, 174ra27 (2013)

7. Rooney, C. M. et al. Infusion of cytotoxic T cells for the prevention and treatment of Epstein-Barr virusinduced lymphoma in allogeneic transplant recipients. Blood 92, 1549-1555 (1998).

8. Heslop, H. E. et al. Long-term outcome of EBVspecific T-cell infusions to prevent or treat EBV-related lymphoproliferative disease in transplant recipients. Blood 115, 925-935 (2010).

9. Bollard, C. M. et al. Sustained complete responses in patients with lymphoma receiving autologous cytotoxic T lymphocytes targeting Epstein-Barr virus latent membrane proteins. J. Clin. Oncol. 32, 798-808 (2014)

10. Eshhar, Z., Waks, T., Gross, G. \& Schindler, D. G. Specific activation and targeting of cytotoxic lymphocytes through chimeric single chains consisting of antibody-binding domains and the $\gamma$ or $\zeta$ subunits of the immunoglobulin and T-cell receptors. Proc. Natl Acad. Sci. USA 90, 720-724 (1993).

11. Annenkov, A. E., Moyes, S. P., Eshhar, Z., Mageed, R. A. \& Chernajovsky, Y. Loss of original antigenic specificity in T cell hybridomas transduced with a chimeric receptor containing single-chain $\mathrm{Fv}$ of an anti-collagen antibody and FceRI-signaling $\gamma$ subunit. J. Immunol. 161, 6604-6613 (1998).

12. Haynes, N. M. et al. Redirecting mouse CTL against colon carcinoma: superior signaling efficacy of singlechain variable domain chimeras containing TCR- $\zeta$ vs FcERl- $\gamma$. J. Immunol. 166, 182-187 (2001).

13. Gross, G., Waks, T. \& Eshhar, Z. Expression of immunoglobulin-T-cell receptor chimeric molecules as functional receptors with antibodytype specificity. Proc. Natl Acad. Sci. USA 86 10024-10028 (1989)

14. Bird, R. E. et al. Single-chain antigen-binding proteins. Science 242, 423-426 (1988).

15. Huston, J. S. et al. Protein engineering of antibody binding sites: recovery of specific activity in an antidigoxin single-chain Fv analogue produced in Escherichia coli. Proc. Natl Acad. Sci. USA 85 5879-5883 (1988).

16. Orlandi, R., Gussow, D. H., Jones, P. T. \& Winter, G. Cloning immunoglobulin variable domains for expression by the polymerase chain reaction. Proc. Natl Acad. Sci. USA 86, 3833-3837 (1989).

17. Hollyman, D. et al. Manufacturing validation of biologically functional T cells targeted to CD 19 antigen for autologous adoptive cell therapy. J. Immunother. 32, 169-180 (2009).

18. Lee, J., Sadelain, M. \& Brentjens, R. Retroviral transduction of murine primary T lymphocytes. Methods Mol. Biol. 506, 83-96 (2009).

19. Quintas-Cardama, A et al. Multifactorial optimization of gammaretroviral gene transfer into human $T$ lymphocytes for clinical application. Hum. Gene Ther. 18 1253-1260 (2007).

20. Brentjens, R. J. et al. Genetically targeted T cells eradicate systemic acute lymphoblastic leukemia xenografts. Clin. Cancer Res. 13, 5426-5435 (2007).

21. Brentjens, R. J. et al. Eradication of systemic B-cell tumors by genetically targeted human $\mathrm{T}$ lymphocytes co-stimulated by CD80 and interleukin-15. Nat. Med. 9 , 279-286 (2003).

22. Huang, X. et al. Sleeping Beauty transposon-mediated engineering of human primary T cells for therapy of CD19 + lymphoid malignancies. Mol. Ther. 16, 580-589 (2008).

23. Kochenderfer, J. N. et al. Construction and preclinical evaluation of an anti-CD 19 chimeric antigen receptor. J. Immunother. 32, 689-702 (2009).

24. Savoldo, B. et al. CD28 costimulation improves expansion and persistence of chimeric antigen receptormodified T cells in lymphoma patients. J. Clin. Invest. 121, 1822-1826 (2011)

25. Wang, X. et al. Phenotypic and functional attributes of lentivirus-modified CD 19-specific human CD8 + central memory $T$ cells manufactured at clinical scale. J. Immunother. 35, 689-701 (2012).

26. Milone, M. C. et al. Chimeric receptors containing CD137 signal transduction domains mediate enhanced survival of T cells and increased antileukemic efficacy in vivo. Mol. Ther. 17, 1453-1464 (2009).

27. Terakura, S. et al. Generation of CD19-chimeric antigen receptor modified CD8 + T cells derived from virus-specific central memory T cells. Blood 119, 72-82 (2012).
28. Zola, H. et al. Preparation and characterization of a chimeric CD 19 monoclonal antibody. Immunol. Cell Biol. 69, 411-422 (1991).

29. Bejcek, B. E. et al. Development and characterization of three recombinant single chain antibody fragments (scFvs) directed against the CD19 antigen. Cancer Res. 55, 2346-2351 (1995)

30. Nicholson, I. C et al. Construction and characterisation of a functional CD19 specific single chain Fv fragment for immunotherapy of B lineage leukaemia and lymphoma. Mol. Immunol. 34, 1157-1165 (1997).

31. Imai, C. et al. Chimeric receptors with 4-1BB signaling capacity provoke potent cytotoxicity against acute lymphoblastic leukemia. Leukemia 18, 676-684 (2004).

32. Till, B. G. et al. Adoptive immunotherapy for indolent non-Hodgkin lymphoma and mantle cell lymphoma using genetically modified autologous CD20-specific T cells. Blood 112, 2261-2271 (2008).

33. Jensen, M. C. et al. Antitransgene rejection responses contribute to attenuated persistence of adoptively transferred CD20/CD19-specific chimeric antigen receptor redirected T cells in humans. Biol. Blood Marrow Transplant. 16, 1245-1256 (2010).

34. Wang, J. et al. Optimizing adoptive polyclonal T cell immunotherapy of lymphomas, using a chimeric T cell receptor possessing CD28 and CD137 costimulatory domains. Hum. Gene Ther. 18, 712-725 (2007).

35. Maher, J., Brentjens, R. J., Gunset, G., Riviere, I. \& Sadelain, M. Human T-lymphocyte cytotoxicity and proliferation directed by a single chimeric TCR / CD28 receptor. Nat. Biotechnol. 20, 70-75 (2002).

36. Hombach, A. A., Rappl, G. \& Abken, H. Arming cytokine-induced killer cells with chimeric antigen receptors: CD28 outperforms combined CD28-OX40 "super-stimulation". Mol. Ther. 21, 2268-2277 (2013).

37. Carpenito, C. et al. Control of large, established tumor xenografts with genetically retargeted human $\mathrm{T}$ cells containing CD28 and CD137 domains. Proc. Natl Acad. Sci. USA 106, 3360-3365 (2009).

38. Zhong, X. S., Matsushita, M., Plotkin, J., Riviere, I. \& Sadelain, M. Chimeric antigen receptors combining 4-1BB and CD28 signaling domains augment PI3kinase/AKT/Bcl-XL activation and CD8 + T cellmediated tumor eradication. Mol. Ther. 18 , 413-420 (2010).

39. Tammana, S. et al. 4-1 BB and CD28 signaling plays a synergistic role in redirecting umbilical cord blood $T$ cells against B-cell malignancies. Hum. Gene Ther. 21 , 75-86 (2010).

40. Pegram, H. J., Park, J. H. \& Brentjens, R. J. CD28z CARs and armored CARs. Cancer J. 20, 127-133 (2014). 
41. Jones, B. S., Lamb, L. S., Goldman, F. \& Di Stasi, A. Improving the safety of cell therapy products by suicide gene transfer. Front. Pharmacol. 5, 254 (2014)

42. Di Stasi, A. et al. T lymphocytes coexpressing CCR4 and a chimeric antigen receptor targeting CD30 have improved homing and antitumor activity in a Hodgkin tumor model. Blood 113, 6392-6402 (2009).

43. Kershaw, M. H. et al. Redirecting migration of T cells to chemokine secreted from tumors by genetic modification with CXCR2. Hum. Gene Ther 13 , 1971-1980 (2002).

44. Brentjens, R. J. et al. Safety and persistence of adoptively transferred autologous CD 19-targeted $T$ cells in patients with relapsed or chemotherapy refractory B-cell leukemias. Blood 118, 4817-4828 (2011).

45. Kalos, M. et al. T cells with chimeric antigen receptors have potent antitumor effects and can establish memory in patients with advanced leukemia. Sci. Transl. Med. 3, 95ra73 (2011).

46. Kochenderfer, J. N. et al. Eradication of B-lineage cells and regression of lymphoma in a patient treated with autologous $T$ cells genetically engineered to recognize CD19. Blood 116, 4099-4102 (2010).

47. Wang, X. \& Riviere, I. Manufacture of tumor- and virusspecific $T$ lymphocytes for adoptive cell therapies. Cancer Gene Ther. 22, 85-94 (2015).

48. Brentjens, R. J. et al. CD19-targeted T cells rapidly induce molecular remissions in adults with chemotherapy-refractory acute lymphoblastic leukemia. Sci. Transl. Med. 5, 177 ra38 (2013).

49. Davila, M. L. et al. Efficacy and toxicity management of 19-28z CAR T cell therapy in B cell acute lymphoblastic leukemia. Sci. Transl. Med. 6, 224 ra25 (2014).

50. Park, J. H. et al. CD19-targeted 19-28z CAR modified autologous T cells induce high rates of complete remission and durable responses in adult patients with relapsed, refractory B-cell ALL [abstract]. Blood 124, a382 (2014).

51. Maude, S. L. et al. Chimeric antigen receptor T cells for sustained remissions in leukemia. N. Engl. J. Med. 371, 1507-1517 (2014).

52. Lee, D. W. et al. T cells expressing CD 19 chimeric antigen receptors for acute lymphoblastic leukaemia in children and young adults: a phase 1 dose-escalation trial. Lancet 385, 517-528 (2015)

53. Fielding, A. K. et al. Outcome of 609 adults after relapse of acute lymphoblastic leukemia (ALL); an MRC UKALL12/ECOG 2993 study. Blood 109, 944-950 (2007)

54. Gökbuget, N. et al. Outcome of relapsed adult lymphoblastic leukemia depends on response to salvage chemotherapy, prognostic factors, and performance of stem cell transplantation. Blood 120 2032-2041 (2012).

55. Kantarjian, H. M. et al. Outcome of adults with acute lymphocytic leukemia in second or subsequent complete remission. Leuk. Lymphoma 51, 475-480 (2010).

56. Curran, K. J. et al. Validation of donor derived virus specific T-lymphocytes genetically modified to target the CD19 antigen for the treatment of relapsed Leukemia. Mol. Ther. 19, S90 (2011).

57. Kochenderfer, J. N. et al. Donor-derived CD19-targeted T cells cause regression of malignancy persisting after allogeneic hematopoietic stem cell transplantation. Blood 122, 4129-4139 (2013).

58. Park, J. H. et al. Impact of the conditioning chemotherapy on outcomes in adoptive T cell therapy: results from a phase I clinical trial of autologous CD19-targeted T cells for patients with relapsed CLL [abstract]. Blood 120, a1797 (2012).

59. Park, J. H. et al. Phase I trial of autologous CD19-targeted CAR-modified T cells as consolidation after purine analog-based first-line therapy in patients with previously untreated CLL [abstract]. J. Clin. Oncol. 32 (5s Suppl.), a7020 (2014).

60. Porter, D. L., Levine, B. L., Kalos, M., Bagg, A \& June, C. H. Chimeric antigen receptor-modified $\mathrm{T}$ cells in chronic lymphoid leukemia. N. Engl. J. Med. 365, 725-733 (2011).

61. Porter, D. L. et al. Chimeric antigen receptor modified t cells directed against CD19 (CTLO19 cells) have long term persistence and induce durable responses in relapsed, refractory CLL [abstract]. Blood 122, a4162 (2013).

62. Porter, D. L. et al. Randomized, phase II dose optimization study of chimeric antigen recepto modified T cells directed against CD19 (CTL019) in patients with relapsed, refractory CLL [abstract]. Blood 124, a1982 (2014).
63. Kochenderfer, J. N. et al. B-cell depletion and remissions of malignancy along with cytokineassociated toxicity in a clinical trial of anti-CD 19 chimeric-antigen-receptor-transduced T cells. Blood 119, 2709-2720 (2012).

64. Kochenderfer, J. N. et al. Chemotherapy-refractory diffuse large B-cell lymphoma and indolent B-cell malignancies can be effectively treated with autologous T cells expressing an anti-CD19 chimeric antigen receptor. J. Clin. Oncol. 33, 540-549 (2015).

65. Kochenderfer, J. N. et al. Anti-CD19 CAR T cells administered after low-dose chemotherapy can induce remissions of chemotherapy-refractory diffuse large B-cell lymphoma [abstract]. Blood 124, a550 (2014).

66. Schuster, S. J. et al. Phase Ila trial of chimeric antigen receptor modified $T$ cells directed against CD19 (CTL019) in patients with relapsed or refractory CD19+ lymphomas [abstract]. Blood 124, a3087 (2014).

67. Sauter, C. S. et al. Interim safety analysis: a phase trial of high dose therapy and autologous stem cell transplantation followed by infusion of chimeric antigen receptor modified T-cells (19-28z CAR-T) directed against CD19 + B-cells for relapsed and refractory aggressive $B$ cell non-Hodgkin lymphoma (B-NHL) [abstract]. Blood 124, a677 (2014).

68. Lee, D. W. et al. Current concepts in the diagnosis and management of cytokine release syndrome. Blood 124, 188-195 (2014)

69. Maude, S. L., Barrett, D., Teachey, D. T. \& Grupp, S. A. Managing cytokine release syndrome associated with novel T cell-engaging therapies. Cancer J. 20 119-122 (2014).

70. Ramos, C. A., Savoldo, B. \& Dotti, G. CD19-CAR trials. Cancer J. 20, 112-118 (2014).

71. Maude, S. L., Teachey, D. T., Porter, D. L. ¿ Grupp, S. A. CD19-targeted chimeric antigen receptor T-cell therapy for acute lymphoblastic leukemia. Blood 125, 4017-4023 (2015).

72. Grupp, S. A. et al. Chimeric antigen receptor-modified T cells for acute lymphoid leukemia. N. Engl. J. Med. 368, 1509-1518 (2013).

73. Turtle, C. J. et al. Immunotherapy with CD19-specific chimeric antigen receptor (CAR)-modified T cells of defined subset composition [abstract]. J. Clin. Oncol. 33 (Suppl.), a3006 (2015).

74. Wang, X. et al. A transgene-encoded cell surface polypeptide for selection, in vivo tracking, and ablation of engineered cells. Blood 118, 1255-1263 (2011).

75. Di Stasi, A. et al. Inducible apoptosis as a safety switch for adoptive cell therapy. N. Engl. J. Med. 365, 1673-1683 (2011)

76. Giordano Attianese, G. M. et al. In vitro and in vivo model of a novel immunotherapy approach for chronic lymphocytic leukemia by anti-CD23 chimeric antigen receptor. Blood 117, 4736-4745 (2011).

77. Berger, C. et al. Safety of targeting ROR 1 in primates with chimeric antigen receptor-modified T cells. Cancer Immunol. Res. 3, 206-216 (2015).

78. Haso, W. et al. Anti-CD22-chimeric antigen receptors targeting B-cell precursor acute lymphoblastic leukemia. Blood 121, 1165-1174 (2013).

79. Vera, J. et al. T lymphocytes redirected against the $\kappa$ light chain of human immunoglobulin efficiently kill mature B lymphocyte-derived malignant cells. Blood 108, 3890-3897 (2006).

80. Savoldo, B. et al. Epstein Barr virus specific cytotoxic T lymphocytes expressing the anti-CD30 $\zeta$ artificial chimeric T-cell receptor for immunotherapy of Hodgkin disease. Blood 110, 2620-2630 (2007).

81. Ruella, M. et al. Novel chimeric antigen receptor T cells for the treatment of Hodgkin lymphoma [abstract]. Blood 124, a806 (2014)

82. Chinnasamy, D. et al. Local delivery of interleukin-12 using $T$ cells targeting VEGF receptor-2 eradicates multiple vascularized tumors in mice. Clin. Cancer Res. 18, 1672-1683 (2012)

83. Craddock, J. A. et al. Enhanced tumor trafficking of GD2 chimeric antigen receptor T cells by expression of the chemokine receptor CCR2b. J. Immunother. 33, 780-788 (2010).

84. Karlsson, S. C. et al. Combining CAR T cells and the Bcl-2 family apoptosis inhibitor ABT-737 for treating B-cell malignancy. Cancer Gene Ther. 20, 386-393 (2013)

85. Pavel, O. et al. Immunomodulatory agent lenalidomide enhances antitumor functions of chimeric receptormodified t cells in vitro and in vivo [abstract]. Blood 124, a805 (2014)

86. John, L. B. et al. Anti-PD-1 antibody therapy potently enhances the eradication of established tumors by gene-modified T cells. Clin. Cancer Res. 19, 5636-5646 (2013).
87. Cruz, C. R. et al. Infusion of donor-derived CD19-redirected-virus-specific T cells for B-cell malignancies relapsed after allogeneic stem cell transplant: a phase I study [abstract]. Blood 122 a 152 (2013)

88. Turtle, C. J. et al. Therapy of B cell malignancies with CD19-specific chimeric antigen receptor-modified $\mathrm{T}$ cells of defined subset composition [abstract]. Blood 124, a384 (2014).

89. Derniame, S. et al. Multiplex genome editing as a platform for "off-the-shelf" adoptive CAR T-cell immunotherapies [abstract]. Blood 124, a1111 (2014).

90. Torikai, H. et al. A foundation for universal T-cell based immunotherapy: $T$ cells engineered to express a CD19-specific chimeric-antigen-receptor and eliminate expression of endogenous TCR. Blood 119, 5697-5705 (2012).

91. June, C. H., Riddell, S. R. \& Schumacher, T. N. Adoptive cellular therapy: a race to the finish line. Sci. Transl. Med. 7, 280ps7 (2015).

92. Mack, M., Riethmuller, G. \& Kufer, P. A small bispecific antibody construct expressed as a functional singlechain molecule with high tumor cell cytotoxicity. Proc. Natl Acad. Sci. USA 92, 7021-7025 (1995).

93. Loffler, A. et al. A recombinant bispecific single-chain antibody, CD19 $\times$ CD3, induces rapid and high lymphoma-directed cytotoxicity by unstimulated T lymphocytes. Blood 95, 2098-2103 (2000).

94. Dreier, T. et al. Extremely potent, rapid and costimulation-independent cytotoxic T-cell response against lymphoma cells catalyzed by a single-chain bispecific antibody. Int. J. Cancer 100, 690-697 (2002).

95. Offner, S., Hofmeister, R., Romaniuk, A., Kufer, P. \& Baeuerle, P. A. Induction of regular cytolytic $T$ cell synapses by bispecific single-chain antibody constructs on MHC class I-negative tumor cells. Mol. Immunol. 43, 763-771 (2006)

96. Schlereth, B. et al. T-cell activation and B-cell depletion in chimpanzees treated with a bispecific anti-CD19/ anti-CD3 single-chain antibody construct. Cancer Immunol. Immunother. 55, 503-514 (2006)

97. Kufer, P. et al. Minimal costimulatory requirements for $T$ cell priming and $T_{4} 1$ differentiation: activation of naive human $\mathrm{T}$ lymphocytes by tumor cells armed with bifunctional antibody constructs. Cancer Immun. 1, 10 (2001).

98. Bargou, R. et al. Tumor regression in cancer patients by very low doses of a $\mathrm{T}$ cell-engaging antibody. Science 321, 974-977 (2008)

99. Haas, C. et al. Mode of cytotoxic action of T cellengaging BiTE antibody MT110. Immunobiology 214 441-453 (2009)

100. Gruen, M., Bommert, K. \& Bargou, R. C. T-cell-mediated lysis of $B$ cells induced by a CD19 $\times$ CD3 bispecific single-chain antibody is perforin dependent and death receptor independent. Cancer Immunol. Immunother. $\mathbf{5 3}$. 625-632 (2004)

101. Klinger, M. et al. Immunopharmacologic response of patients with B-lineage acute lymphoblastic leukemia to continuous infusion of T cell-engaging CD 19/ CD3-bispecific BiTE antibody blinatumomab. Blood 119, 6226-6233 (2012).

102. Nagorsen, D., Kufer, P., Baeuerle, P. A. \& Bargou, R. Blinatumomab: a historical perspective. Pharmacol. Ther. 136, 334-342 (2012)

103. Goebeler, M. E. et al. Final results from a phase study of blinatumomab in patients with relapsed/ refractory non-Hodgkin's lymphoma. Hematol. Oncol. 31, 197 (2013).

104. Swerdlow, S. H. et al. (eds) WHO Classification of Tumours of Haematopoietic and Lymphoid Tissues 4th edn (International Agency for Research on Cancer 2008)

105. Topp, M. S. et al. Long-term follow-up of hematologic relapse-free survival in a phase 2 study of blinatumomab in patients with MRD in B-lineage ALL. Blood 120, 5185-5187 (2012).

106. Topp, M. S. et al. Targeted therapy with the T-cell-engaging antibody blinatumomab of chemotherapy-refractory minimal residual disease in B-lineage acute lymphoblastic leukemia patients results in high response rate and prolonged leukemiafree survival. J. Clin. Oncol. 29, 2493-2498 (2011).

107. Topp, M. S. et al. Phase II trial of the anti-CD 19 bispecific T cell-engager blinatumomab shows hematologic and molecular remissions in patients with relapsed or refractory B-precursor acute lymphoblastic leukemia. J. Clin. Oncol. 32, 4134-4140 (2014). 
108. Topp, M. S. et al. Safety and activity of blinatumomab for adult patients with relapsed or refractory B-precursor acute lymphoblastic leukaemia: a multicentre, single-arm, phase 2 study. Lancet Oncol. $16,57-66$ (2015).

109. Viardot, A. et al. Treatment of relapsed/refractory diffuse large B-cell lymphoma with the Bispecific T-cell Engager $\left(\mathrm{BiTE}^{\oplus}\right)$ antibody construct blinatumomab: primary analysis results from an open-label, phase 2 study [abstract]. Blood 124, a4460 (2014).

110. Zugmaier, G. et al. Long-term follow-up of serum immunoglobulin levels in blinatumomab-treated patients with minimal residual disease-positive B-precursor acute lymphoblastic leukemia. Blood Cancer J. 4, 244 (2014).

111. Goebeler, M. et al. CD3/CD19 bispecific BiTE antibody blinatumomab treatment of non-Hodgkin lymphoma (NHL) patients: $60 \mu \mathrm{g} / \mathrm{m}^{2} / \mathrm{d}$ by continuous infusion is tolerable and results in durable responses [abstract 0559]. Haematologica 95 (Suppl. 2), 230 (2010).

112. Viardot, A. et al. Treatment of patients with non-Hodgkin lymphoma (NHL) with CD19/CD3 bispecific antibody blinatumomab (MT103): double-step dose increase to continuous infusion of $60 \mu \mathrm{g} / \mathrm{m}^{2} / \mathrm{d}$ is tolerable and highly effective [abstract]. Blood 116, a2880 (2010).

113. Holliger, P., Prospero, T. \& Winter, G. "Diabodies": small bivalent and bispecific antibody fragments. Proc. Natl Acad. Sci. USA 90, 6444-6448 (1993).

114. Moore, P. A. et al. Application of dual affinity retargeting molecules to achieve optimal redirected T-cell killing of B-cell lymphoma. Blood 117 4542-4551 (2011).

115. Kipriyanov, S. M. et al. Bispecific tandem diabody for tumor therapy with improved antigen binding and pharmacokinetics. J. Mol. Biol. 293, 41-56 (1999).

116. Brinkmann, U., Reiter, Y., Jung, S. H., Lee, B. \& Pastan, I. A recombinant immunotoxin containing a disulfidestabilized Fv fragment. Proc. Natl Acad. Sci. USA 90 7538-7542 (1993).

117. Johnson, S. et al. Effector cell recruitment with nove Fv-based dual-affinity re-targeting protein leads to potent tumor cytolysis and in vivo B-cell depletion. J. Mol. Biol. 399, 436-449 (2010).

118. Rothe, A. et al. A phase 1 study of the bispecific anti-CD30/CD16A antibody construct AFM13 in patients with relapsed or refractory Hodgkin lymphoma. Blood 125, 4024-4031 (2015)

119. Pardoll, D. M. The blockade of immune checkpoints in cancer immunotherapy. Nat. Rev. Cancer 12 , 252-264 (2012).

120. Dong, H. et al. Tumor-associated B7-H1 promotes T-cell apoptosis: a potential mechanism of immune evasion. Nat. Med. 8, 793-800 (2002)

121. Curiel, T. J. et al. Blockade of B7-H1 improves myeloid dendritic cell-mediated antitumor immunity. Nat. Med. 9, 562-567 (2003).

122. Ruiz-Cabello, F. et al. Phenotypic expression of histocompatibility antigens in human primary tumours and metastases. Clin. Exp. Metastasis 7, 213-226 (1989).

123. Leach, D. R., Krummel, M. F. \& Allison, J. P. Enhancement of antitumor immunity by CTLA-4 blockade. Science 271, 1734-1736 (1996).

124. Linsley, P. S. et al. Intracellular trafficking of CTLA-4 and focal localization towards sites of TCR engagement Immunity 4, 535-543 (1996).

125. Linsley, P. S. et al. Human B7-1 (CD80) and B7-2 (CD86) bind with similar avidities but distinct kinetics to CD28 and CTLA-4 receptors. Immunity 1, 793-801 (1994).

126. Lenschow, D. J. et al. CD28/B7 regulation of $\mathrm{T}_{\mathrm{H}} 1$ and $\mathrm{T}_{\mathrm{H}} 2$ subsets in the development of autoimmune diabetes. Immunity 5, 285-293 (1996).

127. Parry, R. V. et al. CTLA-4 and PD-1 receptors inhibit T-cell activation by distinct mechanisms. Mol. Cell Biol. 25, 9543-9553 (2005)

128. Latchman, Y. E. et al. PD-L1-deficient mice show that PD-L1 on T cells, antigen-presenting cells, and host tissues negatively regulates T cells. Proc. Natl Acad. Sci. USA 101, 10691-10696 (2004).

129. Nishimura, H., Nose, M., Hiai, H., Minato, N. \& Honjo, T. Development of lupus-like autoimmune diseases by disruption of the PD-1 gene encoding an ITIM motifcarrying immunoreceptor. Immunity 11, 141-151 (1999).

130. Gotsman, l. et al. Proatherogenic immune responses are regulated by the PD-1/PD-L pathway in mice. J. Clin. Invest. 117, 2974-2982 (2007).

131. Waterhouse, P. et al. Lymphoproliferative disorders with early lethality in mice deficient in Ctla-4. Science $\mathbf{2 7 0}$ 985-988 (1995)
132. Tivol, E. A. et al. Loss of CTLA-4 leads to massive lymphoproliferation and fatal multiorgan tissue destruction, revealing a critical negative regulatory role of CTLA-4. Immunity 3, 541-547 (1995).

133. Green, M. R. et al. Integrative analysis reveals selective 9p24.1 amplification, increased PD-1 ligand expression, and further induction via JAK2 in nodular sclerosing Hodgkin lymphoma and primary mediastinal large B-cell lymphoma. Blood 116, 3268-3277 (2010).

134. Chen, B. J. et al. PD-L1 expression is characteristic of a subset of aggressive B-cell lymphomas and virusassociated malignancies. Clin. Cancer Res. 19, 3462-3473 (2013)

135. Andorsky, D. J. et al. Programmed death ligand 1 is expressed by non-Hodgkin lymphomas and inhibits the activity of tumor-associated T cells. Clin. Cancer Res. 17 4232-4244 (2011).

136. Naidoo, J., Page, D. B. \& Wolchok, J. D. Immune checkpoint blockade. Hematol. Oncol. Clin. North Am. 28, 585-600 (2014).

137. Green, M. R. et al. Constitutive AP-1 activity and EBV infection induce PD-L1 in Hodgkin lymphomas and posttransplant lymphoproliferative disorders: mplications for targeted therapy. Clin. Cancer Res. 18 1611-1618 (2012).

138. Spranger, S. et al. Up-regulation of PD-L1, IDO, and T in the melanoma tumor microenvironment is driven by CD8 ${ }^{+}$T cells. Sci. Transl. Med. 5, 200 ra116 (2013).

139. Taube, J. M. et al. Association of PD-1, PD-1 ligands, and other features of the tumor immune microenvironment with response to anti-PD-1 therapy. Clin. Cancer Res. 20, 5064-5074 (2014).

140. Steidl, C. et al. MHC class II transactivator CIITA is a recurrent gene fusion partner in lymphoid cancers. Nature 471, 377-381 (2011)

141. Joos, S. et al. Genomic imbalances including amplification of the tyrosine kinase gene JAK2 in CD30+ Hodgkin cells. Cancer Res. 60, 549-552 (2000).

142. Berger, R. et al. Phase I safety and pharmacokinetic study of CT-011, a humanized antibody interacting with PD-1, in patients with advanced hematologic malignancies. Clin. Cancer Res. 14, 3044-3051 (2008).

143. Armand, P. et al. Disabling immune tolerance by programmed death-1 blockade with pidilizumab after autologous hematopoietic stem-cell transplantation for diffuse large B-cell lymphoma: results of an international phase II trial. J. Clin. Oncol. 31, 4199-4206 (2013).

144. Westin, J. R. et al. Safety and activity of PD1 blockade by pidilizumab in combination with rituximab in patients with relapsed follicular lymphoma: a single group, openlabel, phase 2 trial. Lancet Oncol. 15, 69-77 (2014).

145. Timmerman, J. et al. Nivolumab in patients with relapsed or refractory lymphoid malignancies and classical Hodgkin lymphoma: updated results of a phase I study (CA209-039) [abstract]. Hematol. Oncol. 33, a010 (2015)

146. Garcia-Manero, G. et al. A multicohort trial of the safety and efficacy of the PD-1 inhibitor MK-3475 in patients with hematologic malignancies [abstract]. J. Clin. Oncol. 32 (5s Suppl.), TPS3116 (2014).

147. US National Library of Medicine. ClinicalTrials.gov [online], https://clinicaltrials.gov/ct2/show/ NCT01953692 (2015)

148. Ansell, S. M. et al. PD-1 Blockade with nivolumab in relapsed or refractory Hodgkin's lymphoma. N. Engl. J. Med. 372, 311-319 (2015)

149. Armand, P. et al. Nivolumab in patients with relapsed or refractory Hodgkin lymphoma - preliminary safety, efficacy and biomarker results of a phase I study [abstract]. Blood 124, a289 (2014).

150. Moskowitz, C. H. et al. PD-1 blockade with the monoclonal antibody pembrolizumab (MK-3475) in patients with classical Hodgkin lymphoma after brentuximab vedotin failure: preliminary results from phase $1 \mathrm{~b}$ study (KEYNOTE-013) [abstract]. Blood 124 a290 (2014).

151. Brahmer, J. R. et al. Safety and activity of anti-PD-L antibody in patients with advanced cancer. N. Engl. J. Med. 366, 2455-2465 (2012).

152. US National Library of Medicine. ClinicalTrials.gov [online], https://clinicaltrials.gov/ct2/show/ NCT02220842? term $=$ NCT02220842\&rank $=1$ (2015)

153. US National Library of Medicine. ClinicalTrials.gov [online], https://clinicaltrials.gov/ct2/show/ NCT01775631 (2015)

154. Ansell, S. M. et al. Phase I study of ipilimumab, an anti-CTLA-4 monoclonal antibody, in patients with relapsed and refractory B-cell non-Hodgkin lymphoma. Clin. Cancer Res. 15, 6446-6453 (2009).
155. Weber, J. S. Practical management of immune-related adverse events from immune checkpoint protein antibodies for the oncologist. Am. Soc. Clin. Oncol. Educ. Book 2012, 174-177 (2012).

156. Weber, J. S., Yang, J. C., Atkins, M. B. \& Disis, M. L. Toxicities of immunotherapy for the practitioner. J. Clin. Oncol. 33, 2092-2099 (2015).

157. Larkin, J. et al. Combined nivolumab and ipilimumab or monotherapy in untreated melanoma. N. Engl. J. Med. 373, 23-34 (2015).

158. Bristol-Myers Squibb Yervoy (ipilimumab): Immunemediated adverse reaction management guide [online], https://www.hcp.yervoy.com/pdf/rems-managementguide.pdf.

159. Lesokhin, A. M. et al. Preliminary results of a phase study of nivolumab (BMS-936558) in patients with relapsed or refractory lymphoid malignancies [abstract]. Blood 124, a291 (2014).

160. US National Library of Medicine. ClinicalTrials.gov [online], https://clinicaltrials.gov/ct2/show/ NCT02038946? term $=$ NCT02038946\&rank $=1$ (2015)

161. US National Library of Medicine. ClinicalTrials.gov [online], https://clinicaltrials.gov/ct2/show NCT02038933? term $=$ NCT02038933\&rank $=1$ (2015)

162. US National Library of Medicine. ClinicalTrials.gov [online], https://clinicaltrials.gov/ct2/show/ NCT02181738?term $=$ NCT02181738\&rank $=1$ (2015)

163. US National Library of Medicine. ClinicalTrials.gov [online], https://clinicaltrials.gov/ct2/show/ NCT01592370?term $=$ NCT01592370\&rank $=1$ (2015)

164. Garon, E. B. et al. Pembrolizumab for the treatment of non-small-cell lung cancer. N. Engl. J. Med. 372 2018-2028 (2015)

165. Carbognin, L. et al. Differential activity of nivolumab, pembrolizumab and MPDL3280A according to the tumor expression of programmed death-ligand-1 (PD-L1): sensitivity analysis of trials in melanoma, lung and genitourinary cancers. PLOS ONE 10, e0130142 (2015).

166. Snyder, A. et al. Genetic basis for clinical response to CTLA-4 blockade in melanoma. N. Engl. J. Med. 371 2189-2199 (2014)

167. Rizvi, N. A. et al. Cancer immunology. Mutational landscape determines sensitivity to PD-1 blockade in non-small cell lung cancer. Science 348, 124-128 (2015)

168. Tumeh, P. C. et al. PD-1 blockade induces responses by inhibiting adaptive immune resistance. Nature 515 568-571 (2014)

169. Alexandrov, L. B. et al. Signatures of mutational processes in human cancer. Nature $500,415-421$ (2013)

170. Reichel, J. et al. Flow sorting and exome sequencing reveal the oncogenome of primary Hodgkin and Reed-Sternberg cells. Blood 125, 1061-1072 (2015).

171. Lin, J. H. et al. Epstein-Barr virus LMP2A suppresses $\mathrm{MHC}$ class II expression by regulating the B-cell transcription factors E47 and PU.1. Blood 125, 2228-2238 (2015)

172. Bashey, A. et al. CTLA4 blockade with ipilimumab to treat relapse of malignancy after allogeneic hematopoietic cell transplantation. Blood 113 1581-1588 (2009).

\section{Author contributions}

All authors researched data for article, contributed to discussion of the content, wrote the manuscript and reviewed edited the article before submission.

\section{Competing interests statement}

R.J.B. declares he is the Scientific Cofounder of JUNO Therapeutics and receives research support from the National Institutes of Health (grants CA095152, CA 138738 CA059350, CA008748), Juno Therapeutics, the William Cawrence Blanche Hughes Foundation, The Emerald Foundation, the Damon Runyon Clinical Investigator Award the Annual Terry Fox Run for Cancer Research, Kate's Team, the Mr William H. Goodwin and Mrs Alice Goodwin and the Commonwealth Cancer Foundation for Research, the Experimental Therapeutics Center of Memorial Sloan Kettering Cancer Center, and the Geoffrey Beene Cance Foundation. A.Y. receives honoraria from Bayer, BMS, Celgene, Incyte, Janssen R\&D, Sanofi, Seattle Genetics, and Takeda Millenium, and research support from the John and Barbara Vogelstein Foundation. C.L. B is supported by the Mortimer J. Lacher Foundation. E.M. declares no competing interests. 